\title{
The Effect of Bank Levy Introduction on Commercial Banks in Europe
}

\author{
Karolina Puławska
}

Citation: Puławska, Karolina. 2021 The Effect of Bank Levy Introduction on Commercial Banks in Europe. Journal of Risk and Financial Management 14: 279. https:// doi.org/10.3390/jrfm14060279

Academic Editor: Thanasis Stengos

Received: 1 May 2021

Accepted: 18 June 2021

Published: 21 June 2021

Publisher's Note: MDPI stays neutral with regard to jurisdictional claims in published maps and institutional affiliations.

Copyright: (C) 2021 by the author. Licensee MDPI, Basel, Switzerland. This article is an open access article distributed under the terms and conditions of the Creative Commons Attribution (CC BY) license (https:// creativecommons.org/licenses/by/ $4.0 /)$.
Accounting Department, Kozminski University, ul. Jagiellońska 59, 03-301 Warsaw, Poland; k.pulawska@kozminski.edu.pl

\begin{abstract}
We evaluated the effects of the bank levy (BL) on the profitability of commercial banks and the balance sheet reconstruction, and the shifting of banks' activities into countries with lower BL rates after BL introduction. Moreover, we investigated the effects of the Basel III and Single Resolution Fund (SRF) introduction on the amount of BL payment. We compared two different BL designs: the Hungarian and the German versions. The results clearly pointed to the negative effect of BL introduction on the ROA of larger Hungarian commercial banks and of smaller commercial banks in Germany. Moreover, the results showed that the introduction of the BL did not influence loan activity in Hungary. However, it decreased the value of the loans from German commercial banks. The results showed that commercial banks in Hungary prefer to restructure their balance or shift assets among different locations or entities to decrease the bank levy. The research findings also showed that Hungarian commercial banks decreased the value of paid BL after the Basel III introduction. On the other hand, the results also showed that the value of paid BL in German commercial banks increased after the Basel III and SRF introduction, especially in larger banks.
\end{abstract}

Keywords: bank levy; commercial banks; profitability; Basel III; Single Resolution Fund

\section{Introduction}

The financial crisis of 2007-2008 revealed that banks' risky operations can have dramatic consequences for economies. First, banks' losses and the considerable public resources spent on bailing them out can be detrimental regarding other societal needs, and second, banks' bankruptcies have major social and economic consequences throughout the world (Reinhart and Rogoff 2013). Many proposals have been brought forward regarding ways to protect the banking sector against such future turbulence and discourage banks from taking unnecessary risks. One of the proposals, which was heavily debated, presented the introduction of bank levies (International Monetary Fund 2010). Bank levies could help regulate this sector without using direct intervention (European Commission 2010). For this reason, bank levies could be considered a solution applied in order to counteract the negative externalities generated by the financial sector, especially during, but also before and after, economic crises (Mara 2012).

Recently, many countries have decided to apply this regulatory instrument, even though the bank levy (BL) schemes they applied differ. For example, European Union Member States, such as Austria, Belgium, Cyprus, Denmark, Germany, the Netherlands, Latvia, Portugal, Romania, Slovakia, Sweden, and the United Kingdom, have decided to introduce a BL on bank liabilities, while Poland, Slovenia, Finland, and Hungary focused on bank assets. France chose to levy bank capital. Although levy design has been subject to legislative debate, an increasing number of countries are considering its introduction. Therefore, in this paper, we compared two BL models: the BL on assets (referring to the case of Hungary) and the BL on liabilities (German regulations). In both countries, the main motivation was to discourage commercial banks from engaging in risky funding. Therefore, as we compared two different models, our research could be useful for academics who 
are exploring the subject of how financial institutions respond to the introduction of new regulations such as BLs, and for regulators who are currently considering whether to introduce a BL or to change their currently prevailing BL model.

The role of banks has remained crucial in financing economic activities (Kumar and Bird 2020). Therefore, the efficient operation of banks is vital for economic development and social welfare (Yang et al. 2019), and the research interest in bank profitability and efficiency is linked to the economic situation, and an important responsibility of policymakers is to ensure economic stability (Neves et al. 2020). Not surprisingly, the effect of the BL introduction on bank profitability in Europe is of great interest to both scholars and policymakers, especially during turbulent periods such as the COVID-19 pandemic. For example, the Hungarian government is currently engaged in a debate regarding whether a one-off tax on the banking sector that will bolster Hungary's pandemic war chest can be deducted in full from the BL over the subsequent five years (MTI-Hungary 2020).

Our study examined the impact of the BL on the behaviour of German and Hungarian commercial banks. More specifically, we examined: (1) whether the introduction of the BL has affected profitability; (2) whether banks pass the cost of the BL on to their customers by increasing the interest margin on loans, by reducing interest rates on deposits, or by shifting assets within the group to decrease BL burden; and (3) the impact of other regulations on the amount of paid BL. Our study contributed to the existing literature in terms of four important aspects. First, we compared two totally different models of regulation. We decided to analyse the effect of BLs in Hungary (bank levy on assets) and Germany (bank levy on liabilities). Second, our research focused only on commercial banks. Salas and Saurina (2002) found that, compared to commercial banks, the quality of loans granted by savings banks is less sensitive to macroeconomic circumstances, owing to their focus on local and smaller borrowers. Therefore, we investigated the effect of BLs only on commercial banks. Third, we investigated data from a long time period; we considered the period from 2005 to 2015, i.e., 5 years of BL function. We targeted this period because this is a time period during which many changes in bank behaviour occurred due to bank levy introduction. Researchers who have analysed the early impact of BLs noticed that the effect of regulation must be verified over a longer period of time (Buch et al. 2016). Lastly, we investigated the effect of the new regulations such as Basel III and the Single Resolution Fund (SRF) on the amount of paid BL, which has not previously been tested.

Overall, due to the previous research, the BL should not have a strong macroeconomic impact on the behaviour of banks, as it is not significant, and many small commercial banks have been exempted from it due to their small individual size (Buch et al. 2017). However, researchers and experts have also revealed a negative impact from the BL, as it has the potential to increase financial transaction costs and contribute to a decline in the number of transactions and in the overall transaction value. This can thereby lead to a decrease in bank liquidity, wider interest spreads, and higher volatility, resulting in a rise in the prices within banking services (Huizinga et al. 2012; Kolesnika and Dovladbekova 2014). On the other hand, some researchers claim that the BL does not affect banks' profitability, because costs are shifted to customers, or a financial transaction can be transferred to a country in which such taxes do not exist (Albertazzi and Gambacorta 2010; Huizinga et al. 2012). Our research clearly points to the negative effect of BL introduction on the ROA of the larger Hungarian commercial banks and of the smaller commercial banks in Germany. Moreover, the results showed that the introduction of the BL did not influence loan activity in Hungary. However, it decreased the value of the loans of German commercial banks. Additionally, the results showed that larger commercial banks in Hungary do generally prefer to restructure their balance, as larger Hungarian banks become less engaged in risky activities following BL introduction. Moreover, the introduction of the BL in Germany did not affect customer deposits in commercial banks. Moreover, we found that Hungarian institutions try to shift their assets among different locations or entities to decrease the bank levy. The effect seems to be plausible, as extant studies have suggested that financial companies overall are willing to pass taxes (Albertazzi and Gambacorta 2010). 
To the best of our knowledge, to date, no one has studied the impact of the introduction of new regulations such as Basel III and the Single Resolution Fund (SRF) on BL volumes. In December 2010, with regard to the regulatory deficiencies revealed by the crisis, the Basel Committee on Banking Supervision announced Basel III (Committee 2010). Among several guidelines, Basel III is intended to strengthen bank capital requirements and holdings of high-quality liquid assets and decrease bank leverage (Fidrmuc and Lind 2020). The research provides strong arguments that the Basel reforms will make the banking system safer by reducing bank risk-taking and the probability of bank default. The SRF was established by the European Regulation (Single Resolution Mechanism Regulation 2014) and is composed of contributions from credit institutions and certain investment firms in the participating Member States within the European Banking Union. The SRF will build up gradually and shall reach the target level of the amount of covered deposits of all credit institutions within the Banking Union. However, the aim of the BL was also to put a price on the bank's contribution to the systemic risk and, thus, internalise the negative externalities. Moreover, it has been argued that the aim of bank levies is to modify the incentives of banks' management and owners and, thus, persuade them to take into account the bank's contribution to systemic risk (Buch et al. 2017). Others have claimed that BLs allow the taxing of potential economic rents enjoyed by the financial sector, owing to the implicit and explicit state guarantees (Capelle-Blancard and Havrylchyk 2017). Considering that the reason for the establishment of all these three regulations (bank levy, Basel III, and SRF) was the financial crisis of 2007-2008 and that the objectives of these regulations are similar, it is very interesting to witness how the amount of the paid BL (as BL was introduced as the first of these three regulations) was affected by the introduction of the other two, i.e., Basel III and SRF. Our results indicated that, among Hungarian commercial banks, the value of the paid BL decreased after the Basel III introduction. On the other hand, the result showed that, in German commercial banks, the value of the paid BL increased after the Basel III and SRF introduction, especially in larger banks.

Additionally, in our article, we describe in detail the BL models introduced in Hungary and Germany. Based on an extensive literature review, our paper also summarises the advantages and disadvantages of the selected models.

The remainder of the paper proceeds as follows: The next section reviews the literature in order to develop the hypotheses. The third section presents the study in terms of the BL models, sample, and methodology. The fourth section reports the summary statistics, the fifth section analyses the empirical results, and the sixth section presents a robustness check of the results. The final section provides conclusions.

\section{Literature Review and Hypothesis Development}

\subsection{Does the Bank Levy Affect the Profits of Commercial Banks?}

The BL effect is a new topic in the academic literature. The majority of the existing papers on the subject have discussed the context of corporate income taxes. For example, Albertazzi and Gambacorta (2010) analysed aggregated data for OECD countries and concluded that income taxes are passed on to bank customers. In contrast to these findings, Capelle-Blancard and Havrylchyk (2013) argued that corporate income tax is not shifted to customers, as it does not affect the maximisation function of banks.

However, several studies have highlighted that the pass-through effect can only be achieved to a limited extent, and thus the BL might negatively affect bank profitability. For example, Capelle-Blancard and Havrylchyk (2013) documented that banks do not pass their tax burden on to all customers. The authors found that the tax burden is shifted only to long-term customers of the bank, who would have to incur high costs if they decided to switch to another institution. Additionally, Demirgüç-Kunt and Huizinga $(1999,2001)$ found that the pass-on effect depends on the ownership structure. The authors found that local banks pass their corporate income taxes on to customers to a greater extent than foreign banks. Therefore, given that the pass-on effect might be produced to a 
limited extent and, in theory, should negatively affect bank profitability, we formulated the following hypothesis:

Hypothesis 1 (H1). A bank levy will have a significant effect on the profitability of a commercial bank.

\subsection{Do Banks Restructure Their Operation within Their Balance Sheet to Avoid Bank Levy Costs?}

Recent studies have indicated that banks might decrease the tax burden by changing either their balance sheet structure or their business models (Buch et al. 2016). For example, Buch et al. (2016) suggested that banks try to attract funds that are not subject to the levy. Their results also indicated that, in the longer run, banks can change their business models to more retail-based funding in order to pay lower taxes (Buch et al. 2016). Furthermore, Merz and Overesch (2016) used subsidiary-level bank data, and their results suggested that the reported earnings of multinational bank subsidiaries clearly respond to the tax incentives provided by the host country. However, their results also showed that the profit response to taxes is significantly restricted by anti-tax avoidance legislation. Studies have confirmed the shifts between products and the migration of significant trading volumes to the UK (Campbell and Froot 1994; Umlauf 1993).

Bank performance might also not be affected when banks decide to restructure their operations within their balance sheet. Many countries allow banks to exclude certain positions from the calculation of the levy burden. This can result in a relevant shift of bank operations. For example, Buch et al. (2016) documented that the BL in Germany brought about an increase in the deposit rate in order to attract new deposits, as the levy imposed on bank liabilities excluded deposits from the calculation of bank levy burden. This has pushed banks towards deposit sources of funding. Therefore, the following hypothesis was formulated:

Hypothesis 2 (H2). Commercial banks restructure their operation within their balance sheet as a result of levy introduction.

\subsection{Do Banks Shift Their Activities into Countries with a Lower Tax Rate?}

Further studies have also claimed that banks' profits are not affected by the bank levy, as banks might shift their operations into countries with lower or no taxation liabilities. For example, researchers have concluded that foreign banks pay lower taxes in several developed countries and, therefore, suspect that they engage in profit shifting (Claessens et al. 2001; Demirgüç-Kunt and Huizinga 1999). Consequently, the authors showed that the pre-tax profitability of international banks varies little with domestic tax rates, as they can exploit profit shifting opportunities. However, Merz and Overesch (2016) documented that countries with lower taxation experience higher liability, while at the same time, a subsidiary operating in countries with higher taxation rates show a rise in loan loss provisioning or credit defaults to reduce the earnings subject to a high tax rate. The author concluded that banks tend to shift their activities to countries with lower tax rates to decrease the banks' tax burden. Based on these studies, we state the following hypothesis:

Hypothesis 3 (H3). The profitability of banks will be not affected by tax levy, as banks shift their activities into other countries.

\subsection{Have Other Financial Market Regulations Affected the Amount of Bank Levy?}

After the 2008 financial crisis, a number of regulations and organisational bodies were created to safeguard the stability of the financial sector. Among others, Basel III and the SRF were implemented.

In December 2010, with regard to the regulatory deficiencies revealed by the crisis, the Basel Committee on Banking Supervision announced extensive reforms to strengthen the resilience of the financial system, known as Basel III (Committee 2010). The research provided strong arguments that the Basel reforms will make the banking system safer by reducing bank risk-taking and the probability of bank default. Among these several 
guidelines, Basel III is intended to strengthen bank capital requirements by increasing minimum capital requirements and holdings of high-quality liquid assets, and decreasing bank leverage (Fidrmuc and Lind 2020).

The SRF was established by the European Regulation (Single Resolution Mechanism Regulation 2014) and is composed of contributions from credit institutions and certain investment firms in the participating Member States within the European Banking Union. The SRF will be gradually built up and shall reach the target level of the amount of covered deposits of all credit institutions within the Banking Union. The amount and base of payment depend on the financial company value of the assets.

To comply with regulatory standards, banks would have to strengthen their capitalisation and modify the structure of their balance sheet. Thus, adjusting banks to the requirements could affect the change in the balance sheet of banks and also the amount of bank levy paid by banks in the German and Hungarian sectors. Therefore, we hypothesised that:

Hypothesis 4 (H4). Financial market regulations affect the amount of bank levy paid.

\section{Research Design}

3.1. The Structure of Bank Levies in Hungary and Germany

3.1.1. The BL in Hungary

Hungary was one of the first countries to implement the BL. Unlike other countries, Hungary, and later Poland, decided to tax the asset side of the balance sheet of banks. The BL was introduced in Hungary by virtue of an act adopted in July 2010 and has been collected since September 2010. At the time of writing, the tax was presented as a temporary measure, and hence, the tax base was fixed at the amount of assets at 2009. However, very soon, the tax became perceived as a permanent measure, and banks started to expect that the tax base would be changed in the future to reflect the changes in assets. Nevertheless, regulators did not specify how long the bank levy would apply (Capelle-Blancard and Havrylchyk 2013). The purpose of the Hungarian BL was to reduce the deficit of the public budget. Hungary was in the worst recession in 19 years in the last quarter of 2009. Therefore, Hungarian lawmakers approved a bank tax three times larger than levies proposed elsewhere in Europe. The BL was part of a package in Parliament called "Proposal on making and modifying certain economic and financial laws" (T581/190) (Osvat and Osvat 2010).

The BL in Hungary applies to all financial institutions (including branches) with at least one set of annual financial statements prepared by 1 July 2010, including banks, insurance companies, stock exchanges and other financial sector businesses, and foreign branches of EU banks resident in that country, even those operating at a loss. This means that, in the wake of a future crisis, the profitability and the amount of corporate income taxes might decline, but the BL will increase the overall tax burden of Hungarian banks. Moreover, bank levies are not deductible from the corporate income tax. The levy is set at $0.15 \%$ of the tax base for small financial institutions with assets below HUF 50 billion (around EUR 185 million) and at $0.53 \%$ of the tax base for larger institutions. This means that the ratio of total tax paid by large commercial banks has more than tripled from $0.15 \%$ of total assets to $0.53 \%$ (Capelle-Blancard and Havrylchyk 2017).

The proponents of the Hungarian BL stated that, in contrast to assets, customer deposits are more stable, because they are protected by deposit insurance systems (Köhler 2015), they are repriced at a slower pace (Shleifer and Vishny 2010), and they are held for liquidity purposes (Song and Thakor 2007). Thus, they believe that a bank levy based on the size of banks' assets is a better form of discouraging banks from taking higher risks. Additionally, credit derivatives held as an asset class might cause the instability of financial institutions (Partnoy and Skeel 2006). Moreover, Köhler (2015) and DeYoung and Torna (2013) showed that a larger share of income from asset-based nontraditional activities, such as investment banking and asset securitisation, significantly increase the likelihood 
of failure of distressed financial institutions. Researchers have also shown that a higher rate of asset growth makes financial institutions significantly riskier (Altunbas et al. 2011; Demirgüç-Kunt and Huizinga 2010). The advantage of the bank levy formula introduced in Hungary is also that interbank market positions have been excluded. Previous research has shown that a BL on assets applied in Poland has a negative impact on the liquidity of the interbank market (Puławska 2020), as interbank positions were not excluded from the tax base.

\subsubsection{The BL in Germany}

After the financial crisis of 2008, a range of policy approaches have been developed aiming to mitigate the burden on taxpayers and minimise the future reliance on public funds to bail out financial institutions. As financial institutions arrange to strengthen financial stability, the EU defines, for example, bank levies, resolution funds, and deposit guarantee schemes.

The first legislative measure in Germany was the introduction of a rescue fund, financed by the financial industry through a BL. The fund entered into operation in 2011 and applies to all credit institutions with a German banking license, and it is managed by the Federal Agency for Financial Market Stabilisation. Bridge banks, defined as banks established by the Federal Agency for Financial Market Stabilisation to resolve banks in distress, and development banks are excluded from the levy.

$\mathrm{BL}$ is computed on the basis of nonconsolidated financial statements; therefore, all domestic and foreign branches of German banks, subsidiaries of foreign banks located in Germany with a German banking license, are subject to it. There are, however, two exclusions: (1) foreign subsidiaries of German banks are excluded from the regulation, unless they fall under the classification of the German Banking Act and hold a German banking license; (2) branches of non-German banks are exempted from the regulation if they belong to credit institutions in the European Economic Area (Banking Act 1998, sct. 53b). Interestingly, to avoid the double taxation of foreign branches of German banks abroad, Germany signed bilateral agreements with individual countries that BL payments made in Germany are thus deductible from similar payments made abroad (Buch et al. 2016).

In 2014, the European Commission, the European Parliament, and the member states reached an agreement on a Single Resolution Mechanism for all EU member states whose currency is the euro, including setting up an SRF to be raised through contributions by banks in the Eurozone. Germany was one of the first countries to introduce a recovery and resolution regime into its regulatory framework. In December 2010, the Bank Restructuring Act was supplemented by a bank restructuring law, which gave the Federal Financial Supervisory Authority extended powers for dealing with troubled financial institutions (Haag et al. 2020). The levy has objectives to generate resources for a restructuring fund and reduce systemic risk by providing incentives for banks to shift from an over-reliance on short-term interbank financing to more stable funding sources such as customer deposits and equity capital (Kogler 2019). Moreover, the purpose was to create a restructuring fund with a target value of EUR 70 billion, i.e., roughly equal to the public support granted to commercial banks in the period 2008-2013 (EUR 64 billion). In the first three years after the introduction of the bank levy, EUR 1.8 billion have been collected, which gave $2.6 \%$ of the German Restructuring Fund goal. BL will be collected until the target of $100 \%$ is reached.

The calculation of the German BL is based on contribution-relevant liabilities from the previous year's balance sheet. The German bank levy is designed to increase with banks' total liabilities (and thus with bank leverage), from which selected positions (e.g., equity and retail deposits) are deducted, as well as the amount of derivative exposures. Contribution-relevant liabilities are all liabilities, according to the annual statement of the previous financial year ending before 1 March of the contribution year, minus (1) liabilities towards customers, excluding liabilities issued as bearer securities; (2) profit participation rights with a maturity of more than two years; (3) reserve funds for general banking risk; and (4) equity (Buch et al. 2016). 
Contribution-relevant liabilities in 2011 are based on the 2010 balance sheet. They are calculated as the total liabilities minus the bank's equity and customer deposits. Deposits are exempted, as commercial banks are already paying for them to cover deposit insurance. Contribution-relevant liabilities are taxed at a rate that increases progressively. In the case of liabilities between EUR 300 million and EUR 10 billion, the rate is 0.0002 (EUR 300 million < contribution-relevant liabilities $\leq$ EUR 10 billion). In the case of contribution-relevant liabilities exceeding EUR 10 billion, the rate increases to 0.0003. Moreover, bank levies are not deductible from the corporate income tax. As only systemic banks had been rescued, smaller banks benefit from a tax allowance (Buch et al. 2016), which means that the BL rate for large commercial banks, large savings banks, and other large banks is higher (Buch et al. 2017). However, Haskamp (2016) observed the spillover effects of the BL from levy-paying commercial banks to commercial banks in the German financial sector that are not obligated to pay the BL. He claimed that an increase in the lending rates of commercial banks paying the BL caused an increase in the lending rates of institutions exempt from the BL (spillover effect). He noticed the indirect effect on one third of the analysed sample.

BLs on liabilities have an effect similar to a Pigouvian tax and usually target banks' balance sheet positions that are considered to be risky. These items are funding sources other than customer deposits and bank equity (Buch et al. 2016). Therefore, a levy also aims to reduce risk positions of financial institutions. The German BL's base is calculated as total liabilities minus equity and customer deposits; therefore, the risky part of funds, e.g., uninsured deposits and wholesale funding, is taxed (International Monetary Fund 2010). Moreover, many proponents of the BL argue that BL on liabilities would serve as a macro-prudential tool to discourage risky activities. Keen (2011) stated that BL might have a more purposive role in the area of corrective taxation. Policymakers assume that the BL on liabilities will prove a particularly effective tool for mitigating the risks associated with sudden reversals of foreign capital flows (Jiang et al. 2010). Moreover, levies on liabilities should clearly induce financial institutions to rely more on equity funding (Devereux et al. 2013). Financial institutions with more equity funding might hold safer assets because of moral hazard problems caused by limited liability (Allen et al. 2011). This mechanism implies that BLs may potentially dampen the risk in the financial sector by reducing not only funding risk, but also portfolio risk (Devereux et al. 2013). In Germany, the tax is levied on volatile short-term funding, while stable funding, such as equity and deposits, is excluded.

\subsection{Sample}

To test our hypothesis, we used a dataset of commercial banks from the OrbisFocus. We used only commercial banks, based on the assertion of Salas and Saurina (2002), who found that, compared to commercial banks, the quality of loans granted by savings banks is less sensitive to macroeconomic circumstances owing to their focus on local and smaller borrowers. The sample allowed us to compare all German and Hungarian commercial banks over the period 2005-2015, i.e., the pre-BL introduction period in Germany (2005-2010) and Hungary (2008-2009), and the post-BL introduction period in Germany (2011-2015) and Hungary (2010-2015). Consequently, the sample included 218 German and 35 Hungarian banks, which gave 714 observations. However, the panel was unbalanced because of the mergers and acquisitions that took place during this period. In the main analysis, we used balanced panel data, and for the robustness checks in Section 6, we used the unbalanced panel data. Data were collected on an annual basis, and macroeconomic data were sourced from the Central Banks' website.

\subsection{Methodology}

To verify all of our hypotheses, the same period was taken into consideration. In order to examine how the BL influences bank profits, the following model was used:

(1) PROFIT $_{\mathrm{jt}}=\beta_{0}+\beta_{1}$ BL $_{\mathrm{t}}+\beta_{2}$ SIZE $_{\mathrm{jt}-1}+\beta_{3}$ CapitalRatio $_{\mathrm{jt}-1}+\beta_{4}$ CreditRisk $_{\mathrm{jt}-1}+$ $\beta_{5}$ LiquidityRatio $_{j t-1}+\beta_{6}$ Efficiency $_{j t-1}+\beta_{7}$ Inflation $_{j t}+\beta_{8}$ GDPgrowth $_{j t}+\varepsilon_{j t} \beta_{0}=$ 
Intercept term $\beta_{1}=$ Coefficient for the variable from a given hypothesis (H1) $\beta_{2}-$ $\beta_{8}=$ Coefficients for the control variables $j=$ Firm's identifier $t=$ Time as year $\varepsilon_{\mathrm{jt}}=$ Error term

To estimate how the BL introduction has led to the restructuring of the commercial banks' balance sheet asset side, we estimated the following equation:

(2) Credit $_{\mathrm{tj}}=\beta_{0}+\beta_{1} B L_{\mathrm{t}}+\beta_{2}$ SIZE $_{\mathrm{jt}-1}+\beta_{3}$ CapitalRatio $_{\mathrm{jt}-1}+\beta_{4}$ CreditRisk $_{\mathrm{jt}-1}+$ $\beta_{5}$ LiquidityRatio $_{\mathrm{jt}-1}+\beta_{6}$ Efficiency $_{\mathrm{jt}-1}+\beta_{7}$ Inflation $_{\mathrm{jt}}+\beta_{8}$ GDPgrowth $_{\mathrm{jt}}+\varepsilon_{\mathrm{jt}} \beta_{0}=$ Intercept term $\beta_{1}=$ Coefficient for the variable from a given hypothesis (H2) $\beta_{2}-$ $\beta_{8}=$ Coefficients for the control variables $j=$ Firm's identifier $t=$ Time as year $\varepsilon_{\text {jt }}=$ Error term

Furthermore, in order to check whether the German BL introduction has led to the restructuring of the commercial banks' balance sheet liabilities side, we estimated the following equation:

(3) Deposit $_{\mathrm{jt}}=\beta_{0}+\beta_{1} B L_{\mathrm{t}}+\beta_{2}$ SIZE $_{\mathrm{jt}-1}+\beta_{3}$ CapitalRatio $_{\mathrm{jt}-1}+\beta_{4}$ CreditRisk $_{\mathrm{jt}-1}+$ $\beta_{5}$ LiquidityRatio $_{j t-1}+\beta_{6}$ Efficiency $_{j t-1}+\beta_{7}$ Inflation $_{j t}+\beta_{8}$ GDPgrowth $_{j \mathrm{t}}+\varepsilon_{\mathrm{jt}} \beta_{0}=$ Intercept term $\beta_{1}=$ Coefficient for the variable from a given hypothesis (H2) $\beta_{2}-$ $\beta_{8}=$ Coefficients for the control variables $j=$ Firm's identifier $t=$ Time as year $\varepsilon_{\mathrm{jt}}=$ Error term

In order to examine whether the banks shift their activities into countries with lower tax rates, the following model shall be used:

(4) Interbank $_{\mathrm{jt}}=\beta_{0}+\beta_{1} B L_{\mathrm{t}}+\beta_{2}$ SIZE $_{\mathrm{jt}-1}+\beta_{3}$ CapitalRatio $_{\mathrm{jt}-1}+\beta_{4}$ CreditRisk $_{\mathrm{jt}-1}+$ $\beta_{5}$ LiquidityRatio $_{j t-1}+\beta_{6}$ Efficiency $_{j t-1}+\beta_{7}$ Inflation $_{j t}+\beta_{8}$ GDPgrowth $_{j t}+\varepsilon_{j t} \beta_{0}=$ Intercept term $\beta_{1}=$ Coefficient for the variable from a given hypothesis (H3) $\beta_{2}-$ $\beta_{8}=$ Coefficients for the control variables $j=$ Firm's identifier $t=$ Time as year $\varepsilon_{\mathrm{jt}}=$ Error term

Moreover, in order to check whether the Basel III and SRF introduction has led to the decrease in the amount of paid $\mathrm{BL}$, to test our 4th hypothesis, we estimated the following equation:

(5) $\quad$ BLpaid $_{\mathrm{jt}}=\beta_{0}+\beta_{1}$ Regulation $_{\mathrm{t}}+\beta_{2}$ SIZE $_{\mathrm{jt}-1}+\beta_{3}$ CapitalRatio $_{\mathrm{jt}-1}+\beta_{4}$ CreditRisk $_{\mathrm{jt}-1}+$ $\beta_{5}$ LiquidityRatio $_{j t-1}+\beta_{6}$ Efficiency $_{j t-1}+\beta_{7}$ Inflation $_{j t}+\beta_{8}$ GDPgrowth $_{j \mathrm{t}}+\varepsilon_{\mathrm{jt}} \beta_{0}=\mathrm{In}-$ tercept term $\beta_{1}=$ Coefficient for the variable from a given hypothesis (H4) $\beta_{2}-\beta_{8}=$ Coefficients for the control variables $j=$ Firm's identifier $t=$ Time as year $\varepsilon_{j t}=$ Error term

The construction of all variables is explained in Table 1.

To estimate the regression, we used the GLS estimator with random effects. For verification of Hypotheses 1, 2, and 4, we used unconsolidated financial statements, following the model from Bourke (1989). As conglomerate commercial banks might make certain adjustments and shift their activities among entities to decrease the tax burden, we used the consolidated statements to verify the 3rd hypothesis (Díaz et al. 2004). The choice of the model has been dictated by the specification test by Hausman (1978). In addition, we clustered the standard errors on the level of the commercial bank. We used lagged values for all variables related to commercial banks' characteristics, because these measures are endogenous to the commercial bank's profit. We considered a one-year lag in models due to the limited number of observations. Finally, we added a year dummy in models (1)-(3) to control for any other changes in regulations. 
Table 1. Explanation and construction of all variables used.

\begin{tabular}{|c|c|c|c|}
\hline Label & Explanation & & Measurement \\
\hline \multicolumn{4}{|c|}{ Dependent Variables } \\
\hline PROFIT & $\begin{array}{l}\text { The excess of total revenue over total cost during a } \\
\text { specific period of time. We used the ratios that } \\
\text { have been previously widely used in the literature } \\
\text { (Borio et al. 2017; Gambacorta and Shin 2018). }\end{array}$ & $\begin{array}{l}\text { (1) } \\
\text { (2) } \\
(3)\end{array}$ & $\begin{array}{l}\text { The natural logarithm of profit before tax at a } \\
\text { commercial bank; } \\
\text { Profit before tax to total assets ratio; } \\
\text { Return on average assets ratio. }\end{array}$ \\
\hline CREDIT & $\begin{array}{l}\text { Information about an amount that a client owes to } \\
\text { a commercial bank. These ratios have already been } \\
\text { referred to by several scholars (Borio et al. 2017; } \\
\text { Fahlenbrach et al. 2017; Gilje et al. 2016). Other } \\
\text { earning assets include this variable, derivatives, } \\
\text { and other off-balance sheet activities. }\end{array}$ & $\begin{array}{l}(1) \\
(2) \\
(3) \\
(4) \\
(5)\end{array}$ & $\begin{array}{l}\text { Loans growth; } \\
\text { Natural logarithm of loans; } \\
\text { Loans to total assets; } \\
\text { Natural logarithm of other earnings assets; } \\
\text { Other earnings assets to total asset. }\end{array}$ \\
\hline DEPOSIT & $\begin{array}{l}\text { Money placed into commercial banks by customers } \\
\text { for safekeeping. These ratios have been widely } \\
\text { referred to in the literature (Gilje et al. 2016). }\end{array}$ & $\begin{array}{l}(1) \\
(2) \\
(3)\end{array}$ & $\begin{array}{l}\text { Deposit growth; } \\
\text { Natural logarithm of deposit; } \\
\text { Deposit to total liabilities. }\end{array}$ \\
\hline Interbank & $\begin{array}{l}\text { Loans owed by the bank to the other bank with the } \\
\text { maturity of } 3 \mathrm{~m}, 1 \mathrm{y}\end{array}$ & $\begin{array}{l}(1) \\
(2)\end{array}$ & $\begin{array}{l}\text { Interbank ratio (interbank loans to banks' } \\
\text { total assets); } \\
\text { Growth in loans to banks. }\end{array}$ \\
\hline
\end{tabular}

Simulated amount of bank levy payments during each year. We calculated an estimate of the amount of bank levy paid as BL paid by institutions in Hungary and Germany. The tax base of the BL in Hungary consists of assets of credit institutions excluding interbank assets, which are deducted to avoid double taxation. The levy is determined as $0.15 \%$ of the tax base for small credit institutions with assets under EUR 185 million (HUF 50 billion) Paid and $0.53 \%$ of the tax base for large institutions. The Bank Levy German tax base depends on "Contribution-relevant liabilities", which are total liabilities minus equity, customer deposits, profit participation rights, and reserve funds for general banking risk. This is the total liabilities minus equity, customer deposits, profit participation rights, and reserve funds for general banking risk. Banks are exempted from the levy if their contribution-relevant liabilities are smaller than or equal to EUR 300 million.

Natural logarithm of amount calculated according to national regulation.

\section{Control variables}

We assigned a value of one for all years starting from the introduction year onward and a value of zero for all previous years. The inclusion of this variable was especially important, as it allows us to distinguish between the risk effects stemming from diversification and those of an associated

Dummy if a company j paid bank levy in a year of $t$, then equals 1 ; otherwise, zero. amount of paid levy. Moreover, it is common among other authors to use this dummy variable to control BL introduction (Devereux et al. 2019). 
Table 1. Cont.

\begin{tabular}{|c|c|c|}
\hline Label & Explanation & Measurement \\
\hline Size & $\begin{array}{l}\text { Commercial bank size has been shown to be an } \\
\text { important determinant of a bank's profitability } \\
\text { (Menicucci and Paolucci 2016). We used log } \\
\text { transformation to allow for a possible nonlinear } \\
\text { relation with profitability. }\end{array}$ & Natural logarithm of total asset. \\
\hline Capital ratio & $\begin{array}{l}\text { This ratio measures the institution's financial } \\
\text { strength and should have an effect on the } \\
\text { profitability of the commercial bank } \\
\text { (Tran et al. 2016). }\end{array}$ & Total equity to total assets ratio. \\
\hline Credit Risk & $\begin{array}{l}\text { Credit risk is an important factor influencing the } \\
\text { financial sector. It incorporates the default risk of } \\
\text { the principal and the interest on loans extended by } \\
\text { a bank (Angbazo 1997). }\end{array}$ & Loan loss provisions to total assets \\
\hline Liquidity & $\begin{array}{l}\text { We used the liquidity ratio defined as the ability of } \\
\text { a financial institution to fund increases in assets } \\
\text { and meet obligations as they become due, without } \\
\text { incurring unacceptable losses. Research has shown } \\
\text { that more liquid commercial banks are less } \\
\text { profitable, because commercial banks that hold } \\
\text { highly liquid assets tend to have relatively lower } \\
\text { income, as liquid assets are less risky and, } \\
\text { therefore, attract lower rates of returns } \\
\text { (Kashyap et al. 2002). }\end{array}$ & $\begin{array}{l}\text { Current assets to total assets. } \\
\text { Current assets are cash, accounts receivables, } \\
\text { inventories, short-term investment, and prepaid } \\
\text { expenses. }\end{array}$ \\
\hline Efficiency & $\begin{array}{l}\text { We controlled for the bank's efficiency; existing } \\
\text { research has confirmed that inefficient commercial } \\
\text { banks are less profitable (Oral and Yolalan 1990). }\end{array}$ & Noninterest expenses to net income ratio. \\
\hline Inflation & $\begin{array}{l}\text { Inflation creates pressure for financial institutions } \\
\text { to modify their behaviour in competing for funds } \\
\text { and make financial institutions more keenly aware } \\
\text { of higher interest rates on money market } \\
\text { instruments (Arpa et al. 2001). }\end{array}$ & Value of inflation in a given year. \\
\hline GDP growth & $\begin{array}{l}\text { Demirgüç-Kunt et al. (2004) noted that both } \\
\text { inflation and economic growth can influence } \\
\text { interest margins. }\end{array}$ & Value of GDP growth in a given year. \\
\hline Regulation & $\begin{array}{l}\text { Regulation is the dummy variable that takes the } \\
\text { value of } 1 \text { for years in which the considered } \\
\text { regulation was applied, and } 0 \text { otherwise. We } \\
\text { assumed that Hungarian and German banks were } \\
\text { influenced by Basel III after } 2013 \text {. Nevertheless, the } \\
\text { reform and its parameters were announced in } \\
\text { advance to give commercial banks enough } \\
\text { opportunity to meet the new regulatory } \\
\text { requirements (Andrle et al. 2017). Therefore, we } \\
\text { tended to consider the examined period as a good } \\
\text { proxy to assess the effects of Basel III. We assumed } \\
\text { that German banks have been influenced by SRF } \\
\text { since } 2015 \text { (Single Resolution Mechanism } \\
\text { Regulation 2014). }\end{array}$ & $\begin{array}{l}\text { Dummy if a regulation was in force in a given year, } \\
\text { then equals } 1 \text {; otherwise, zero. }\end{array}$ \\
\hline
\end{tabular}

\section{Summary Statistics}

The table below presents the summary statistics of the unconsolidated financial statements of Hungarian and German commercial banks for the entire sample period (2005-2015):

Table 2 presents the summary statistics of unconsolidated financial statements of Hungarian and German commercial banks during the period of 2005-2015. Data in Table 2 
indicate that Hungarian commercial banks had a higher ROA and profit-to-total-asset ratio than German commercial banks did during these periods.

Table 2. Data presenting summary statistics of unconsolidated financial statements of Hungarian and German commercial banks for the entire period of 2005-2015.

\begin{tabular}{|c|c|c|c|c|c|c|c|c|c|c|}
\hline \multirow[b]{2}{*}{ VARIABLES } & \multicolumn{5}{|c|}{ Hungarian Commercial Banks } & \multicolumn{5}{|c|}{ German Commercial Banks } \\
\hline & $\mathbf{N}$ & Mean & Sd & Min & Max & $\mathbf{N}$ & Mean & Sd & Min & Max \\
\hline Efficiency & 107 & 4.133 & 0.374 & 1.893 & 4.589 & 614 & 3.778 & 1.767 & -2.299 & 5.598 \\
\hline GDP growth $(\%)$ & 107 & 0.888 & 2.985 & -6.564 & 4.047 & 614 & 1.424 & 1.503 & -5.619 & 4.080 \\
\hline Inflation $(\%)$ & 107 & 3.033 & 2.386 & -0.223 & 6.066 & 614 & 1.006 & 0.778 & 0.2 & 3.1 \\
\hline Liquidity Ratio (\%) & 107 & 0.356 & 0.252 & 0.001 & 0.931 & 614 & 0.178 & 0.196 & 0.000 & 0.995 \\
\hline Credit Risk (\%) & 107 & 0.500 & 1.800 & -6.400 & 20.200 & 614 & 0.001 & 0.0058141 & -0.041 & 0.039 \\
\hline $\operatorname{ROA}(\%)$ & 107 & 1.273012 & 2.75548 & -7.666 & 14.987 & 614 & 0.890 & 5.546385 & -1 & 66 \\
\hline Total Asset, in EUR K & 107 & $2,070,600$ & $4,379,000$ & $21,295.86$ & $21,924,000$ & 614 & $41,300,000$ & $472,000,000$ & 449 & $11,800,000$ \\
\hline Capital Ratio (\%) & 107 & 66.103 & 19.777 & 6.641 & 98.415 & 614 & 69.802 & 27.398 & 0 & 269.697 \\
\hline Profit to total asset (\%) & 107 & 1.542 & 3.158 & -7.375 & 18.520 & 614 & 0.408 & 0.409 & -1.339 & 0.6 .360 \\
\hline (ln) Profit before tax & 107 & 14.618 & 1.827 & 9.210 & 18.901 & 614 & 8.818 & 1.843 & 0.000 & 16.784 \\
\hline $\begin{array}{l}\text { Hungary: other earning } \\
\text { assets }(\ln )\end{array}$ & 107 & 17.701 & 2.107 & 12.170 & 22.156 & & & & & \\
\hline $\begin{array}{l}\text { Germany: Customer } \\
\text { deposits }(\ln )\end{array}$ & & & & & & 614 & 13.896 & 1.998 & 3.638 & 23.079 \\
\hline
\end{tabular}

\section{Results}

\subsection{Does the Bank Levy Affect the Profits of Commercial Banks? The Hungarian Experience}

This section presents evidence on how the BL affects the profitability of commercial banks. To this end, we present the regression results on unconsolidated financial statements. Table 3 presents the regression results on all Hungarian commercial banks. We have included the interactive term BL*Total Asset to control for the fact that larger commercial banks must pay higher taxes, and we thus argue that their profitability will be affected more significantly. The results are presented in Table 3.

Table 3. Data presenting estimates based on GLS regressions with a random effect on Hungarian commercial banks. Symbols $* * *$, and ${ }^{* * *}$ represent statistical significance at the levels of $10 \%, 5 \%$, and $1 \%$, respectively.

\begin{tabular}{|c|c|c|c|c|c|c|}
\hline & \multicolumn{6}{|c|}{ Commercial Banks } \\
\hline & $\begin{array}{l}\text { Profit before Tax } \\
\text { (ln) }\end{array}$ & $\begin{array}{l}\text { Profit before Tax } \\
\text { (ln) }\end{array}$ & $\begin{array}{l}\text { Profit before Tax to } \\
\text { Total Assets }\end{array}$ & $\begin{array}{l}\text { Profit before Tax to } \\
\text { Total Assets }\end{array}$ & Return on Assets & Return on Assets \\
\hline VARIABLES & (1) & (2) & (3) & (4) & (5) & (6) \\
\hline \multirow[t]{2}{*}{ Efficiency } & 0.0111 & 0.0174 & 0.001 & 0.003 & 0.008 & 0.013 \\
\hline & $(0.00826)$ & $(0.0155)$ & $(0.013)$ & $(0.016)$ & $(0.008)$ & $(0.010)$ \\
\hline \multirow[t]{2}{*}{ GDP growth } & 2.362 & -0.300 & 1.300 * & 0.485 & 0.990 * & 0.370 \\
\hline & (2.446) & $(0.952)$ & $(0.650)$ & $(0.583)$ & (0.459) & $(0.387)$ \\
\hline \multirow{2}{*}{ Inflation } & 1.633 & -0.480 & 0.658 & 0.0106 & 0.558 & 0.065 \\
\hline & $(1.810)$ & $(0.672)$ & $(0.517)$ & $(0.519)$ & $(0.382)$ & $(0.384)$ \\
\hline \multirow[t]{2}{*}{ Capital Ratio } & 0.178 & 0.109 & 0.007 & -0.0141 & 0.008 & -0.007 \\
\hline & $(0.139)$ & $(0.0932)$ & $(0.080)$ & $(0.0737)$ & $(0.068)$ & $(0.063)$ \\
\hline \multirow[t]{2}{*}{ Credit Risk } & -7.839 & 6.015 & $-9.450 * * *$ & $-5.210 * * *$ & $-2.05^{* * *}$ & $-2.82 * * *$ \\
\hline & (7.616) & $(5.489)$ & $(2.369)$ & $(1.439)$ & $(1.145)$ & $(1.438)$ \\
\hline \multirow[t]{2}{*}{ Liquidity ratio } & 4.285 & $-0.0278^{*}$ & 1.907 & 0.587 & 0.935 & -0.0705 \\
\hline & $(3.742)$ & $(2.849)$ & (3.001) & $(3.050)$ & (2.483) & $(2.501)$ \\
\hline \multirow[t]{2}{*}{ SIZE } & -0.0410 & $-0.101^{*}$ & -0.085 & -0.103 & -0.102 & -0.116 \\
\hline & $(0.0739)$ & $(0.0548)$ & $(0.082)$ & $(0.080)$ & $(0.069)$ & $(0.067)$ \\
\hline \multirow{2}{*}{ BL } & 0.001 & 0.010 & 0.001 & 0.001 & 0.000 & 0.000 \\
\hline & $(0.000)$ & $(0.010)$ & $(0.013)$ & $(0.000)$ & $(0.000)$ & $(0.000)$ \\
\hline \multirow[t]{2}{*}{ BL*Total Asset } & & $0.001 * *$ & & $0.000^{* *}$ & & -0.000 ** \\
\hline & & $(0.000)$ & & $(0.000)$ & & $(0.000)$ \\
\hline \multirow[t]{2}{*}{ Constant } & 2.921 & $26.66^{* *}$ & -1.370 & $0.898^{*}$ & -0.654 & $4.879 * *$ \\
\hline & (11.88) & $(4.765)$ & (2.563) & $(2.896)$ & $(1.849)$ & $(2.080)$ \\
\hline Number of obs. & 60 & 60 & 60 & 60 & 60 & 60 \\
\hline R-squared & 0.462 & 0.728 & 0.493 & 0.429 & 0.412 & 0.444 \\
\hline
\end{tabular}

As mentioned previously, the Hungarian tax authority introduces different levy rates depending on the size of institutions. Banks with assets exceeding HUF 50 billion are heavily taxed at a rate of $0.53 \%$, whereas other commercial banks pay $0.15 \%$. Therefore, we 
tested whether the effect of the BL on the profitability of the commercial bank is stronger in larger commercial banks than in smaller commercial banks. The estimation results on the profitability measures of commercial banks clearly pointed to a very small but negative effect of the BL on the ROA of the larger Hungarian commercial banks. On the other hand, we noticed a small and positive impact on profits of the banks.

Theoretically, the magnitude of the effect is not as straightforward, as larger commercial banks, often operating as conglomerates, tend to shift their profits between different entities and locations to reduce the tax burden (Demirgüç-Kunt and Huizinga 2001). These results demonstrate that the levy has impacted only the profitability of larger Hungarian commercial banks, as only the interaction term is statistically significant. This could be due to the tax minimisation policy (Warfield and Linsmeier 1992). Moreover, it could be attributed to the fact that the more significantly the industry is dominated by a small number of banks, the greater the share of tax costs passed onto customers and the smaller the cost borne by shareholders. In more concentrated industries, customers have relatively fewer alternative options and, therefore, tend to be less mobile across banks. This then gives large banks greater market power to increase interest rates and fees without losing customers (Tennant and Sutherland 2014). However, we tested whether banks transfer their activities within their conglomerates in Section 5.6.

In the context of other explanatory variables, the results are also barely statistically significant. This could be due to the fact that inflation and GDP growth are positively correlated with profitability, which is consistent with the research of Dietrich and Wanzenried (2011) and Olson and Zoubi (2011), who found a significant increase in the profitability of commercial banks during periods of GDP growth. Moreover, the result shows that credit risk decreases the profits of Hungarian commercial banks.

\subsection{The Bank Levy and Balance Sheet Restructuring-The Hungarian Experience}

In this section, we estimate whether the BL leads to a shift in the bank's portfolio. According to the ECB, banks might change their risk profile by restructuring their portfolios in favour of riskier products; for this purpose, they make use of off-balance sheet activities. Empirically, Merz and Overesch (2016), as well as Buch et al. (2016), supported this by showing that banks make shifts in their portfolios towards positions with a lower tax burden. To this end, we regressed the levy variable on the bank loan position. We expect the introduction of the BL to result in a reduction in loans, as banks might wish to reduce their tax burden. If this is the case, a negative effect of the BL on loan dynamics and loan portfolio would be observed in regressions. Table 4 presents the regression results. Just as in the previous regression, we wish to distinguish between the effects on larger and smaller banks; we have, therefore, included the interactive term.

According to the estimation results presented in Table 4, the levy appears statistically significant only in specifications (2) and (4). Therefore, it cannot be concluded that the introduction of the BL has significantly and strongly affected the loan activity. Table 4 suggests a differential impact of the levy on the loan growth of smaller and larger banks. Coefficients indicate that the levy has had a greater impact on the loan portfolio of larger banks compared to smaller entities. Furthermore, Claessens et al. (2010) suggested that the introduction of the BL could lead to an increase in loan rates, which brings increased monthly repayments on a loan. Increased lending rates can trigger a decrease in lending volumes. Regarding the effect of other variables, commercial banks' size negatively affects loan growth. Moreover, an increase in liquidity brings an increase in the value of loans. 
Table 4. Data presenting estimates based on GLS regressions with a random effect on all Hungarian commercial banks. Symbols $* * *$, and ${ }^{* *}$ represent statistical significance at the levels of $10 \%, 5 \%$, and $1 \%$, respectively.

\begin{tabular}{|c|c|c|c|c|c|c|}
\hline \multirow[b]{3}{*}{ VARIABLES } & \multicolumn{6}{|c|}{ All Hungarian Commercial Banks } \\
\hline & \multicolumn{2}{|c|}{ Loans Growth } & \multicolumn{2}{|c|}{ Loans to Total Asset } & \multicolumn{2}{|c|}{ Loans (ln) } \\
\hline & (1) & (2) & (3) & (4) & (5) & (6) \\
\hline \multirow[t]{2}{*}{ Efficiency } & 0.002 & 0.002 & 0.050 & 0.0463 & 0.004 & 0.002 \\
\hline & $(0.002)$ & $(0.002)$ & $(0.112)$ & $(0.106)$ & $(0.003)$ & $(0.003)$ \\
\hline \multirow[t]{2}{*}{ GDP Growth } & -0.032 & -0.044 & -0.897 & -1.254 & -0.199 & -0.145 \\
\hline & $(0.087)$ & $(0.087)$ & $(3.974)$ & $(4.026)$ & $(0.152)$ & $(0.158)$ \\
\hline \multirow[t]{2}{*}{ Inflation } & 0.003 & -0.008 & 0.339 & -0.0581 & -0.212 & -0.142 \\
\hline & $(0.063)$ & $(0.064)$ & $(3.291)$ & $(3.375)$ & $(0.132)$ & $(0.139)$ \\
\hline \multirow[t]{2}{*}{ Capital Ratio } & 0.034 & $0.037^{*}$ & 1.219 & 1.161 & 0.0041 & 0.0275 \\
\hline & $(0.021)$ & $(0.021)$ & $(0.975)$ & $(0.967)$ & $(0.036)$ & $(0.0421)$ \\
\hline \multirow[t]{2}{*}{ Credit Risk } & 0.000 & 0.000 & 0.000 & 0.000 & -0.000 & 0.000 \\
\hline & $(0.000)$ & $(0.000)$ & $(0.000)$ & $(0.000)$ & $(0.000)$ & $(0.000)$ \\
\hline \multirow[t]{2}{*}{ Liquidity Ratio } & 0.091 & 0.058 & $6.35^{* *}$ & $2.70 * *$ & 0.090 & 0.699 * \\
\hline & $(0.174)$ & $(0.182)$ & $(14.81)$ & (14.19) & $(0.253)$ & $(0.381)$ \\
\hline \multirow[t]{2}{*}{ SIZE } & -0.030 & $-0.035^{* *}$ & $-1.313^{* *}$ & $-1.330^{* *}$ & -0.043 & -0.0378 \\
\hline & $(0.010)$ & $(0.018)$ & $(0.598)$ & $(0.558)$ & $(0.029)$ & $(0.0359)$ \\
\hline \multirow[t]{2}{*}{ BL } & 0.000 & 0.001 * & -0.000 & 0.000 & 0.000 & 0.000 \\
\hline & $(0.000)$ & $(0.00)$ & $(0.000)$ & $(0.000)$ & $(0.000)$ & $(0.000)$ \\
\hline \multirow[t]{2}{*}{ BL*Total Asset } & & $-0.000^{* * *}$ & & $-0.001 *$ & & 0.000 \\
\hline & & $(0.000)$ & & $(0.000)$ & & $(0.000)$ \\
\hline \multirow[t]{2}{*}{ Constant } & 0.083 & 0.222 & $5.53^{* *}$ & $1.02 * *$ & $1.35^{* * *}$ & $1.20^{* * *}$ \\
\hline & $(0.356)$ & $(0.351)$ & (20.62) & (22.45) & $(1.022)$ & (1.051) \\
\hline \multirow{2}{*}{$\begin{array}{l}\text { Number of obs. } \\
\text { R-squared }\end{array}$} & 60 & 60 & 60 & 60 & 60 & 60 \\
\hline & 0.537 & 0.492 & 0.395 & 0.379 & 0.322 & 0.650 \\
\hline
\end{tabular}

As suggested, banks can also try to shift their assets into off-balance sheet activities with the goal of reducing their tax burden. To test this effect, we used the variable of other earnings assets to total assets in the regression, as this variable includes derivatives and other off-balance sheet activities. We also included the logarithm of other earnings assets, as the ratio might not change if the nominator and denominator change by similar percentages. If such a warning has been supported, we would see a positive effect of the BL variable on the off-balance sheet proxy in the Hungarian banking sector. Table 5 presents the regression results. Just as in the previous regression, we wish to distinguish between the effect on larger and smaller banks, so we have included the interactive term. We expect larger banks to be more likely to shift their assets, owing to a more complex financial structure.

The estimation results presented in Table 5 show that, throughout the specification, the levy appears statistically significant. The results show that larger commercial banks generally prefer to restructure their balance. The results suggest that, following the BL introduction, larger banks become less engaged in risky activities (Hoenig and Morris 2014).

In terms of the effect of other variables, efficient commercial banks are less likely to have a higher ratio of other earnings to total assets. The results might suggest that commercial banks do not try to compensate for higher costs through investing in another earnings asset. 
Table 5. Data presenting estimates based on GLS regressions with a random effect on Hungarian commercial banks. Symbols $* * *$, and ${ }^{* *}$ represent statistical significance at the levels of $10 \%, 5 \%$, and $1 \%$, respectively.

\begin{tabular}{|c|c|c|c|c|}
\hline \multirow[b]{3}{*}{ VARIABLES } & \multicolumn{4}{|c|}{ Commercial Hungarian Banks } \\
\hline & \multicolumn{2}{|c|}{ Other Earning Asset to Total Assets } & \multicolumn{2}{|c|}{ Other Earning Assets (ln) } \\
\hline & (1) & (2) & (3) & (4) \\
\hline \multirow[t]{2}{*}{ Efficiency } & $0.001^{*}$ & 0.001 * & -0.001 & 0.001 * \\
\hline & $(0.002)$ & $(0.001)$ & $(0.007)$ & $(0.007)$ \\
\hline \multirow[t]{2}{*}{ GDP Growth } & 0.009 & 0.015 & -0.122 & -0.056 \\
\hline & $(0.044)$ & $(0.044)$ & $(0.087)$ & $(0.106)$ \\
\hline \multirow[t]{2}{*}{ Inflation } & 0.003 & 0.007 & $-0.181^{* *}$ & -0.115 \\
\hline & $(0.036)$ & $(0.036)$ & $(0.085)$ & $(0.102)$ \\
\hline \multirow[t]{2}{*}{ Capital Ratio } & -0.014 & -0.013 & -0.0034 & -0.004 \\
\hline & $(0.009)$ & $(0.009)$ & $(0.0365)$ & $(0.032)$ \\
\hline \multirow[t]{2}{*}{ Credit Risk } & $-0.000 * * *$ & $-0.000^{* *}$ & -0.001 & -0.000 \\
\hline & $(0.000)$ & $(0.000)$ & $(0.008)$ & $(0.000)$ \\
\hline \multirow[t]{2}{*}{ Liquidity Ratio } & $-0.466^{* * *}$ & $-0.429 * *$ & -0.502 & -0.671 \\
\hline & $(0.181)$ & $(0.182)$ & $(0.621)$ & $(0.696)$ \\
\hline \multirow[t]{2}{*}{ SIZE } & $0.0178^{* *}$ & $-0.017^{* *}$ & 0.0149 & 0.0258 \\
\hline & $(0.009)$ & $(0.007)$ & $(0.0502)$ & $(0.0455)$ \\
\hline \multirow[t]{2}{*}{$\mathrm{BL}$} & -0.000 & $-0.001 *$ & 0.001 & -0.001 * \\
\hline & $(0.000)$ & $(0.001)$ & $(0.000)$ & $(0.000)$ \\
\hline \multirow[t]{2}{*}{ BL* Total Asset } & & $0.002 * *$ & & $0.001^{* * *}$ \\
\hline & & $(0.001)$ & & $(0.000)$ \\
\hline \multirow[t]{2}{*}{ Constant } & $0.485^{* *}$ & 0.432 ** & $1.45^{* * *}$ & $1.49^{* * *}$ \\
\hline & $(0.198)$ & $(0.215)$ & $(0.818)$ & $(0.734)$ \\
\hline \multirow{2}{*}{$\begin{array}{l}\text { Number of obs. } \\
\text { R-squared }\end{array}$} & 60 & 60 & 60 & 60 \\
\hline & 0.570 & 0.542 & 0.271 & 0.654 \\
\hline
\end{tabular}

\subsection{Does the Bank Levy Affect the Profits of Commercial Banks?-The German Experience}

This section documents how the BL affects the profitability of commercial banks in Germany. Unlike Hungary, Germany imposed a bank levy on the liabilities of commercial banks. We argue that commercial bank profits will be affected as the cost of raising funds increases. Just as in the Hungarian case, we checked whether larger commercial banks have been more affected by the BL than smaller entities. Table 6 outlines the regression results of commercial banks.

The estimation results on the profitability measures of commercial banks clearly point to a negative effect of the BL only on ROA in German commercial banks. The outcome suggests that, when the BL was introduced, the profitability measure (ROA) of German commercial banks significantly decreased. Considering that the banks' activity is related to intermediating capital, the taxation of banks is strictly connected to the taxation of capital (Huizinga 2004), namely, the return on financial assets. As mentioned above, the German tax authority decided to introduce different levy rates depending on the size of the entity. Therefore, just as in the Hungarian sample, we tested whether the effect of the $\mathrm{BL}$ on the profitability of commercial banks is stronger in larger commercial banks. The interaction variable BL*Relevant Liabilities suggests that smaller commercial banks operating in Germany are more significantly affected than larger entities.

Considering other explanatory variables, we found that liquidity is negatively correlated with profit in German commercial banks. This might also be explained by the fact that, compared to illiquid assets, liquid assets tend to generate lower returns. Thus, its higher ratio will lower bank revenue (Sahyouni and Wang 2018). Moreover, commercial banks' size is positively correlated with profits before tax. This is consistent with the result obtained by Olson and Zoubi (2011). 
Table 6. Data presenting estimates based on GLS regressions with a random effect on German commercial banks. Symbols $* * *$, and ${ }^{* * *}$ represent statistical significance at the levels of $10 \%, 5 \%$, and $1 \%$, respectively.

\begin{tabular}{|c|c|c|c|c|c|c|}
\hline \multirow[b]{3}{*}{ VARIABLES } & \multicolumn{6}{|c|}{ Commercial Banks } \\
\hline & \multicolumn{2}{|c|}{ Profit before Tax (ln) } & \multicolumn{2}{|c|}{$\begin{array}{l}\text { Profit before Tax to Total Assets } \\
(\%)\end{array}$} & \multicolumn{2}{|c|}{ Return on Assets } \\
\hline & (1) & (2) & (3) & (4) & (5) & (6) \\
\hline \multirow[t]{2}{*}{ Efficiency } & 0.005 & -0.005 & -0.294 & -0.000 & $0.001 *$ & 0.000 \\
\hline & $(0.0019)$ & $(0.001)$ & $(0.007)$ & $(0.000)$ & $(0.006)$ & $(0.001)$ \\
\hline \multirow[t]{2}{*}{ GDP growth } & 0.044 & 0.0500 & -0.082 & -0.0836 & -0.052 & -0.0549 \\
\hline & $(0.195)$ & $(0.193)$ & $(0.120)$ & $(0.119)$ & $(0.101)$ & $(0.102)$ \\
\hline \multirow[t]{2}{*}{ Inflation } & -0.001 & -0.001 & -1.222 & -0.001 & -0.001 & -0.000 \\
\hline & $(0.000)$ & $(0.001)$ & $(1.003)$ & $(0.000)$ & $(0.001)$ & $(0.000)$ \\
\hline \multirow[t]{2}{*}{ Capital Ratio } & 0.363 & -0.406 & -0.184 & -0.386 & $-0.450 *$ & -0.580 \\
\hline & $(3.485)$ & $(3.086)$ & $(0.985)$ & $(0.904)$ & $(0.546)$ & $(0.544)$ \\
\hline \multirow[t]{2}{*}{ Credit Risk } & $0.000 * * *$ & $0.001^{* * *}$ & 0.000 & 0.000 & 0.001 & 0.000 \\
\hline & $(0.000)$ & $(0.001)$ & $(0.000)$ & $(0.000)$ & $(0.001)$ & $(0.000)$ \\
\hline \multirow[t]{2}{*}{ Liquidity ratio } & $-2.124 *$ & $-2.097^{*}$ & $-0.472^{* *}$ & $-0.446^{* *}$ & -0.227 & -0.205 \\
\hline & (1.312) & $(1.312)$ & $(0.222)$ & $(0.213)$ & $(0.164)$ & $(0.160)$ \\
\hline \multirow[t]{2}{*}{ SIZE } & $0.840^{* * *}$ & $0.901^{* * *}$ & $0.022 * *$ & $0.685^{* *}$ & $-0.029 *$ & -0.0258 \\
\hline & $(0.0504)$ & $(0.0503)$ & $(0.024)$ & $(0.0230)$ & $(0.0148)$ & $(0.017)$ \\
\hline \multirow[t]{2}{*}{ BL } & -0.000 & -0.001 & -0.000 & -0.001 & -0.039 * & -0.038 * \\
\hline & $(0.000)$ & $(0.000)$ & $(0.000)$ & $(0.000)$ & $(0.001)$ & $(0.001)$ \\
\hline BL*Relevant & & $-0.001^{* *}$ & & $-0.001^{* *}$ & & -0.000 \\
\hline Liabilities & & $(0.000)$ & & $(0.000)$ & & $(0.000)$ \\
\hline \multirow[t]{2}{*}{ Constant } & $0.906^{* *}$ & $-1.385 *$ & $0.906^{* *}$ & 0.734 * & $0.763 *$ & 0.725 * \\
\hline & $(0.455)$ & $(0.968)$ & $(0.455)$ & $(0.442)$ & $(0.338)$ & $(0.339)$ \\
\hline Number of obs. & 257 & 257 & 257 & 257 & 257 & 257 \\
\hline R-squared & 0.472 & 0.716 & 0.472 & 0.550 & 0.506 & 0.523 \\
\hline
\end{tabular}

\subsection{The Bank Levy and Balance Sheet Restructuring-The German Experience}

In this section, we estimate whether the German BL leads to shifts in bank portfolios. Buch et al. (2016) and Merz and Overesch (2016) have shown that banks shift their portfolio towards positions with a lower tax burden. To this end, we regressed the levy variable on the bank loan position in Table 7.

The estimation results presented in Table 7 show that the loan growth and natural logarithm of loans from larger banks decrease after the BL introduction. This effect can be observed in specifications (2) and (6). The result seems to be in line with Buch et al. (2016), who showed that banks restructure their balance sheets to decrease the tax burden rather than limit their credit activity.

Moreover, the results show that liquidity is negatively correlated with all loan-to-asset ratios and to the loan value. This means that less-liquid banks tend to decrease the value of loans. Kashyap et al. (2002) provided evidence that the less-liquid banks' decision to reduce the volume of lending could be driven by loan demand factors (i.e., illiquid banks could have more cyclical borrowers). Moreover, high liquidity ratios denote a strong ability to face the sudden liquidity needs of the market and should be reflected in the lower interest rates paid to lenders. Therefore, this can explain the negative correlation (D'Auria et al. 1999).

Additionally, the loan-to-asset ratio is positively affected by inflation, and the number of profitable projects in terms of the expected net present value is greater when the economic situation improves, hence the increased demand for credit (Kashyap et al. 1993). Consequently, the loan-to-asset ratio increases in direct proportion to the inflation rate. 
Table 7. Data presenting estimates based on GLS regressions with a random effect on all German commercial banks. Symbols ${ }^{*}, * *$ and ${ }^{* *}$ represent statistical significance at the levels of $10 \%, 5 \%$, and $1 \%$, respectively.

\begin{tabular}{|c|c|c|c|c|c|c|}
\hline & \multicolumn{6}{|c|}{ Commercial Banks } \\
\hline & Loan Growth & Loan Growth & Loan to Assets & Loan to Assets & Loan(ln) & Loan(ln) \\
\hline VARIABLES & (1) & (2) & (3) & (4) & (5) & (6) \\
\hline Efficiency & $\begin{array}{l}-0.665 \\
(0.958)\end{array}$ & $\begin{array}{c}0.860 \\
(0.110)\end{array}$ & $\begin{array}{c}0.019 \\
(0.024)\end{array}$ & $\begin{array}{c}-0.002 * * * \\
(0.001)\end{array}$ & $\begin{array}{l}-0.001 \\
(0.007)\end{array}$ & $\begin{array}{c}-0.0014 \text { * } \\
(0.001)\end{array}$ \\
\hline GDP Growth & $\begin{array}{c}0.205 \\
(0.362)\end{array}$ & $\begin{array}{l}-0.211 \\
(0.366)\end{array}$ & $\begin{array}{l}-0.083 \\
(0.055)\end{array}$ & $\begin{array}{l}-0.023 \\
(0.002)\end{array}$ & $\begin{array}{l}-0.080 \\
(0.087)\end{array}$ & $\begin{array}{c}0.126 \\
(0.0921)\end{array}$ \\
\hline Inflation & $\begin{array}{l}-0.001 \\
(0.001)\end{array}$ & $\begin{array}{c}0.001 \\
(0.001)\end{array}$ & $\begin{array}{l}-0.099 \\
(0.067)\end{array}$ & $\begin{array}{c}0.100 * * \\
(0.008)\end{array}$ & $\begin{array}{l}-0.000 \\
(0.000)\end{array}$ & $\begin{array}{c}0.001 \\
(0.001)\end{array}$ \\
\hline Capital Ratio & $\begin{array}{c}0.564 \\
(0.749)\end{array}$ & $\begin{array}{c}0.741 \\
(0.939)\end{array}$ & $\begin{array}{c}0.166 \\
(0.192)\end{array}$ & $\begin{array}{l}-0.001 \\
(0.177)\end{array}$ & $\begin{array}{c}5.412 \\
(4.747)\end{array}$ & $\begin{array}{c}4.607 \\
(4.796)\end{array}$ \\
\hline Credit Risk & $\begin{array}{l}0.001 \text { * } \\
(0.001)\end{array}$ & $\begin{array}{c}-0.001 * \\
(0.001)\end{array}$ & $\begin{array}{l}-0.001 \\
(0.001)\end{array}$ & $\begin{array}{l}-0.001 \\
(0.001)\end{array}$ & $\begin{array}{c}0.000 \\
(0.000)\end{array}$ & $\begin{array}{c}-0.001 \text { ** } \\
(0.001)\end{array}$ \\
\hline Liquidity Ratio & $\begin{array}{l}-0.559 \\
(0.309)\end{array}$ & $\begin{array}{c}0.047 \\
(0.301)\end{array}$ & $\begin{array}{c}-0.206^{* * *} \\
(0.056)\end{array}$ & $\begin{array}{c}-0.157^{* *} \\
(0.072)\end{array}$ & $\begin{array}{c}-0.451 \text { * } \\
(0.262)\end{array}$ & $\begin{array}{c}0.415 \\
(0.264)\end{array}$ \\
\hline SIZE & $\begin{array}{l}-0.023 \\
(0.028)\end{array}$ & $\begin{array}{c}-0.033 \text { * } \\
(0.036)\end{array}$ & $\begin{array}{l}-0.003 \\
(0.005)\end{array}$ & $\begin{array}{l}-0.010 \\
(0.008)\end{array}$ & $\begin{array}{l}0.246^{*} \\
(0.150)\end{array}$ & $\begin{array}{c}0.220 \\
(0.151)\end{array}$ \\
\hline $\mathrm{BL}$ & $\begin{array}{l}-2.001 \\
(0.991)\end{array}$ & $\begin{array}{l}-0.011 \\
(0.001)\end{array}$ & $\begin{array}{c}0.014 \\
(0.017)\end{array}$ & $\begin{array}{c}0.012 \\
(0.022)\end{array}$ & $\begin{array}{l}-0.000 \\
(0.000)\end{array}$ & $\begin{array}{l}-0.001 \\
(0.001)\end{array}$ \\
\hline $\begin{array}{c}\text { BL*Relevant } \\
\text { Liabilities }\end{array}$ & & $\begin{array}{l}0.001 * * \\
(0.001)\end{array}$ & & $\begin{array}{l}-0.001 \\
(0.001)\end{array}$ & & $\begin{array}{c}0.001^{* * *} \\
(0.001)\end{array}$ \\
\hline Constant & $\begin{array}{c}-0.090 \\
(0.481)\end{array}$ & $\begin{array}{l}-0.005 \\
(0.442)\end{array}$ & $\begin{array}{c}0.788^{* *} \\
(0.154)\end{array}$ & $\begin{array}{c}0.060^{* *} \\
(0.130)\end{array}$ & $\begin{array}{c}9.948^{* * *} \\
(2.564)\end{array}$ & $\begin{array}{c}10.41^{* * *} \\
(2.606)\end{array}$ \\
\hline $\begin{array}{l}\text { Number of obs. } \\
\text { R-squared }\end{array}$ & $\begin{array}{c}257 \\
0.530\end{array}$ & $\begin{array}{l}257 \\
0.611\end{array}$ & $\begin{array}{c}257 \\
0.391\end{array}$ & $\begin{array}{c}257 \\
0.4522\end{array}$ & $\begin{array}{l}257 \\
0.453\end{array}$ & $\begin{array}{c}257 \\
0.364\end{array}$ \\
\hline
\end{tabular}

Moreover, as suggested above, banks could also try to shift their liabilities into exempted parts of liabilities in order to reduce their tax burden. To test this effect, we used the variables customer deposit growth, deposit-to-asset ratio, and customer deposit (ln) in the regression to see if German banks try to shift their liabilities onto their customer deposits in an attempt to reduce their tax burden. Table 8 presents the regression results.

The estimation results from Table 8 show that the BL does not appear to be statistically significant in any specification. Therefore, we cannot conclude that the introduction of the BL in Germany has significantly affected customer deposits in commercial banks.

However, the results seem to suggest that the size of banks influences the deposit value. Larger banks seem most likely to increase the number of deposits. These results are in line with the recent academic research. Economic theory and empirical evidence also suggest that small banks' ability to raise deposits can constrain their lending activity. This constraint is also connected with more limited diversification opportunities (Houston and James 1998).

Additionally, the results show that liquidity is positively correlated with deposit growth. This means that more liquid banks tend to increase the value of deposits. This conclusion is consistent with the extant research stating that liquid banks experience fewer deposit withdrawals (Martinez Peria and Schmukler 2001). Moreover, the results show that, during periods of macroeconomic growth, clients tend to withdraw deposits. It has been proven that the interest rate on deposits is negatively correlated with the GDP. A higher level of income increases the demand for deposits and, therefore, reduces incentives for banks to set higher deposit rates (Gambacorta 2008). 
Table 8. Data presenting estimates based on GLS regressions with a random effect on all German commercial banks. Symbols $* * *$, and ${ }^{* *}$ represent statistical significance at the levels of $10 \%, 5 \%$, and $1 \%$, respectively.

\begin{tabular}{|c|c|c|c|c|c|c|}
\hline & \multicolumn{6}{|c|}{ Commercial Banks } \\
\hline & $\begin{array}{l}\text { Deposit } \\
\text { Growth }\end{array}$ & $\begin{array}{l}\text { Deposit } \\
\text { Growth }\end{array}$ & $\begin{array}{c}\text { Deposit to } \\
\text { Assets }\end{array}$ & $\begin{array}{c}\text { Deposit to } \\
\text { Assets }\end{array}$ & Deposit (ln) & Deposit (ln) \\
\hline VARIABLES & (1) & (2) & (3) & (4) & (5) & (6) \\
\hline \multirow[t]{2}{*}{ Efficiency } & 10.104 & 0.001 & 0.583 * & 0.001 * & -0.001 & 0.001 \\
\hline & $(0.106)$ & $(0.001)$ & $(0.375)$ & $(0.002)$ & $(0.001)$ & $(0.001)$ \\
\hline \multirow[t]{2}{*}{ GDP Growth } & -0.228 & 0.228 & $-0.451 *$ & -0.034 & -0.154 & 0.140 \\
\hline & $(0.302)$ & $(0.302)$ & $(0.235)$ & $(0.022)$ & $(0.229)$ & $(0.234)$ \\
\hline \multirow[t]{2}{*}{ Inflation } & -0.000 & -0.001 & $-0.122 *$ & -0.001 & -0.001 & 0.001 \\
\hline & $(0.000)$ & $(0.001)$ & $(0.026)$ & $(0.001)$ & $(0.001)$ & $(0.001)$ \\
\hline \multirow[t]{2}{*}{ Capital Ratio } & $-1.594^{* * *}$ & $-1.568^{* * *}$ & -0.338 & -0.467 & 1.753 * & 1.097 * \\
\hline & $(0.386)$ & $(0.383)$ & $(1.273)$ & $(1.233)$ & $(0.224)$ & (9.384) \\
\hline \multirow[t]{2}{*}{ Credit Risk } & 0.001 & -0.001 & -0.001 & $0.001^{* * *}$ & 0.001 & 0.001 \\
\hline & $(0.001)$ & $(0.001)$ & $(0.001)$ & $(0.001)$ & $(0.007)$ & $(0.001)$ \\
\hline \multirow[t]{2}{*}{ Liquidity Ratio } & $7.224 *$ & $6.226^{*}$ & -0.156 & 0.101 & 1.031 & 1.020 \\
\hline & $(4.251)$ & $(4.248)$ & $(0.122)$ & $(0.114)$ & $(0.705)$ & $(0.720)$ \\
\hline \multirow[t]{2}{*}{ SIZE } & 0.432 & 0.003 & 0.0269 & $0.442 * *$ & $0.893^{* * *}$ & $0.894^{* * *}$ \\
\hline & $(0.193)$ & $(0.024)$ & $(0.0243)$ & $(0.021)$ & $(0.191)$ & $(0.204)$ \\
\hline \multirow[t]{2}{*}{ BL } & 12.269 & 4.785 & 0.001 & 0.001 & -0.002 & -0.001 \\
\hline & $(1.228)$ & $(3.361)$ & $(0.000)$ & $(0.00)$ & $(0.001)$ & $(0.001)$ \\
\hline BL*Relevant & & -0.001 & & -0.001 & & 0.001 \\
\hline Liabilities & & $(0.001)$ & & $(0.000)$ & & $(0.001)$ \\
\hline \multirow[t]{2}{*}{ Constant } & 0.527 & 0.542 & 0.355 & 0.0945 & -0.810 & $11.210^{* * *}$ \\
\hline & $(0.578)$ & $(0.608)$ & $(0.473)$ & $(0.438)$ & (3.655) & $(0.718)$ \\
\hline \multirow{2}{*}{$\begin{array}{l}\text { Number of obs. } \\
\text { R-squared }\end{array}$} & 257 & 257 & 257 & 257 & 257 & 257 \\
\hline & 0.375 & 0.386 & 0.296 & 0.356 & 0.590 & 0.600 \\
\hline
\end{tabular}

\subsection{Do Banks Shift Their Activities into Countries with a Lower Tax Rate?}

One of our main hypotheses assumes that bank levies do not affect the bank profitability, as banks might try to reduce their tax exposure by shifting their asset/liabilities not only within their balance sheet and structure but also to other locations and related entities (Demirgüç-Kunt and Huizinga 1999, 2001; Merz and Overesch 2016). We tested the effect of shifting activities into countries with a lower tax rate only for Hungary, as most banks in Hungary are foreign-owned subsidiaries with a limited international presence. In fact, only $47 \%$ of Hungarian banks have Hungarian headquarters (Money.hu 2021). In Germany, a share of less than $5 \%$ of total banking assets were under foreign ownership during the analysed period; therefore, we were unable to test these effects on consolidated data (Statista 2019).

To show that multinational banks tend to shift their activities within their group, we used interbank transactions (which are exempted from taxes in Hungary), while domestic banks tend to shift within their balance sheet as well on customers. We ran the regression on interbank loans, as well as interbank transactions, using the results on unconsolidated versus consolidated accounts. If multinational banks shift their activities within a group, we should see a positive effect of tax levies on consolidated accounts with no effect on unconsolidated statements. Table 9 presents the regression results.

The estimation results in Table 9 show that the effect of the bank levy is statistically significant in models (3) and (4), suggesting that the BL introduction has an effect on the interbank ratio of conglomerates. This supports the findings of other studies that institutions try to shift their asset among different locations or entities to decrease the tax burden, as suggested by other authors. 
Table 9. Do banks shift their activities into countries with lower tax rate? Symbols *, and ** represent statistical significance at the levels of $10 \%$, and $5 \%$, respectively.

\begin{tabular}{|c|c|c|c|c|}
\hline & \multicolumn{2}{|c|}{ Unconsolidated Financial Data-Hungary } & \multicolumn{2}{|c|}{ Consolidated Financial Data-Hungary } \\
\hline & Interbank Ratio & $\begin{array}{c}\text { Growth in Loans to } \\
\text { Banks }\end{array}$ & Interbank Ratio & $\begin{array}{c}\text { Growth in Loans to } \\
\text { Banks }\end{array}$ \\
\hline VARIABLES & (1) & (2) & (3) & (4) \\
\hline Efficiency & $\begin{array}{c}-0.048^{* *} \\
(0.020)\end{array}$ & $\begin{array}{c}0.000 \\
(0.003)\end{array}$ & $\begin{array}{l}0.864 \text { * } \\
(0.522)\end{array}$ & $\begin{array}{c}0.004 \\
(0.005)\end{array}$ \\
\hline GDP Growth & $\begin{array}{l}-21.038 \\
(19.343)\end{array}$ & $\begin{array}{l}-0.178 \\
(0.255)\end{array}$ & $\begin{array}{c}-53.022^{* *} \\
(27.135)\end{array}$ & $\begin{array}{c}-0.704^{* *} \\
(0.301)\end{array}$ \\
\hline Inflation & $\begin{array}{l}-29.964 \\
(19.070)\end{array}$ & $\begin{array}{l}-0.343 \\
(0.245)\end{array}$ & $\begin{array}{l}-43.536 \\
(29.986)\end{array}$ & $\begin{array}{c}-0.685^{* *} \\
(0.338)\end{array}$ \\
\hline Capital Ratio & $\begin{array}{c}0.225 \\
(0.357)\end{array}$ & $\begin{array}{l}-0.008 \\
(0.015)\end{array}$ & $\begin{array}{c}3.945 \\
(3.127)\end{array}$ & $\begin{array}{c}0.008 \\
(0.017)\end{array}$ \\
\hline Credit Risk & $\begin{array}{l}50.885^{*} \\
(30.439)\end{array}$ & $\begin{array}{l}-1.017 \\
(1.451)\end{array}$ & $\begin{array}{c}309.847 \\
(488.324)\end{array}$ & $\begin{array}{c}1.360 \\
(4.494)\end{array}$ \\
\hline Liquidity Ratio & $\begin{array}{l}-66.162 \\
(44.901)\end{array}$ & $\begin{array}{l}0.622 * * \\
(0.251)\end{array}$ & $\begin{array}{c}20.727 \\
(81.005)\end{array}$ & $\begin{array}{l}-0.714 \\
(0.506)\end{array}$ \\
\hline SIZE & $\begin{array}{c}-4.563^{* *} \\
(1.998)\end{array}$ & $\begin{array}{l}-0.025 \\
(0.018)\end{array}$ & $\begin{array}{c}0.266 \\
(6.417)\end{array}$ & $\begin{array}{c}0.042 \\
(0.068)\end{array}$ \\
\hline BL & $\begin{array}{c}119.299 \\
(115.338)\end{array}$ & $\begin{array}{c}0.149 \\
(1.811)\end{array}$ & $\begin{array}{c}355.296 * * \\
(163.032)\end{array}$ & $\begin{array}{l}4.687^{* *} \\
(1.905)\end{array}$ \\
\hline Number of obs. & 76 & 46 & 67 & 43 \\
\hline R-squared & 0.097 & 0.407 & 0.4795 & 0.424 \\
\hline
\end{tabular}

5.6. Have Other Financial Market Regulations Affected the Amount of the Bank Levy? The Hungarian and German Experience

This section shows how regulatory changes impacting the balance sheet of an institution affected its bank levy. We analysed the impact of Basel III on the amount of bank levy paid by Hungarian (models 1 and 2) and German (models 3 and 4) banks and the impact of the introduction of the SRF on the amount of bank levy paid by commercial banks in Germany (models 5 and 6). To analyse the impact of new regulations, we added new variables to the model. Regulation is the dummy variable that takes a value of 1 for the years during which the considered regulation was applied, and 0 otherwise. We assumed that Hungarian and German banks were influenced by Basel III after 2013. We assumed that German banks have been influenced by the SRF since 2015 (Single Resolution Mechanism Regulation 2014). Table 10 presents the regression results.

The estimation results presented in Table 10 show that the introduction of regulations impacted the value of the paid bank levy. The coefficients indicate that the regulation in Hungary has impacted the value of the paid bank levy to a larger bank stronger than to smaller banks. The results show that, among Hungarian commercial banks, the value of the paid bank levy decreased after the Basel III introduction. On the other hand, the German commercial banks' value of the paid bank levy increased after the Basel III and SRF introduction, especially in larger banks. Additionally, the analysed regulations affected larger banks more significantly.

The results meet our expectation, because one of the main features of Basel III is to increase the level and quality of capital and decrease the illiquid assets, which resulted in changes in the banks' balance sheets. Therefore, we observed the increase in BL paid by German banks, as the German BL depends on inter alia equity, and a decrease in BL paid by Hungary, as the Hungarian BL depends on assets. Additionally, we found that the introduction of the SRF correlates positively with the value of paid BL by German commercial banks. The reason for this might be the common dependence on the size of the bank's balance sheet. 
Table 10. Have other financial market regulations affected the amount of bank levy. The Hungarian and German experience. Symbols $* * *$, and ${ }^{* *}$ represent statistical significance at the levels of $10 \%, 5 \%$, and $1 \%$, respectively.

\begin{tabular}{|c|c|c|c|c|c|c|}
\hline & \multicolumn{2}{|c|}{ Commercial Banks-Hungary } & \multicolumn{4}{|c|}{ Commercial Banks-Germany } \\
\hline & $\begin{array}{l}\text { Value of Paid } \\
\text { Bank Levy and } \\
\text { Basel III }\end{array}$ & $\begin{array}{c}\text { Value of Paid } \\
\text { Bank Levy and } \\
\text { Basel III }\end{array}$ & $\begin{array}{c}\text { Value of Paid } \\
\text { Bank Levy and } \\
\text { Basel III }\end{array}$ & $\begin{array}{c}\text { Value of Paid } \\
\text { Bank and Levy } \\
\text { Basel III }\end{array}$ & $\begin{array}{c}\text { Value of Paid } \\
\text { Bank Levy and } \\
\text { SRF }\end{array}$ & $\begin{array}{c}\text { Value of Paid } \\
\text { Bank Levy and } \\
\text { SRF }\end{array}$ \\
\hline VARIABLES & (1) & (2) & (3) & (4) & (5) & (6) \\
\hline Efficiency & $\begin{array}{c}-0.007^{* * *} \\
(0.002)\end{array}$ & $\begin{array}{c}-0.005^{* * *} \\
(0.002)\end{array}$ & $\begin{array}{l}-0.002 \\
(0.004)\end{array}$ & $\begin{array}{l}-0.002 \\
(0.003)\end{array}$ & $\begin{array}{l}-0.003 \\
(0.004)\end{array}$ & $\begin{array}{l}-0.003 \\
(0.004)\end{array}$ \\
\hline GDP growth & $\begin{array}{c}1.448^{* * *} \\
(0.204)\end{array}$ & $\begin{array}{c}1.415^{* * *} \\
(0.220)\end{array}$ & $\begin{array}{c}-0.130 * * * \\
(0.0377)\end{array}$ & $\begin{array}{c}-0.175^{* * *} \\
(0.044)\end{array}$ & $\begin{array}{c}-0.075 \text { * } \\
(0.042)\end{array}$ & $\begin{array}{c}-0.093^{* *} \\
(0.045)\end{array}$ \\
\hline Inflation & $\begin{array}{l}-0.183 \\
(0.744)\end{array}$ & $\begin{array}{l}-0.298 \\
(0.753)\end{array}$ & $\begin{array}{c}0.147 \\
(0.130)\end{array}$ & $\begin{array}{c}0.182 \\
(0.131)\end{array}$ & $\begin{array}{c}-0.559 * * * \\
(0.101)\end{array}$ & $\begin{array}{c}-0.580 * * * \\
(0.101)\end{array}$ \\
\hline Capital Ratio & $\begin{array}{c}-0.00305 \\
(0.0808)\end{array}$ & $\begin{array}{l}-0.025 \\
(0.071)\end{array}$ & $\begin{array}{c}1.843 \\
(1.572)\end{array}$ & $\begin{array}{l}1.260 \\
(1.228)\end{array}$ & $\begin{array}{c}0.926 \\
(1.617)\end{array}$ & $\begin{array}{c}0.964 \\
(1.612)\end{array}$ \\
\hline Credit Risk & $\begin{array}{l}0.001 \text { ** } \\
(0.001)\end{array}$ & $\begin{array}{l}0.001 * * \\
(0.001)\end{array}$ & $\begin{array}{c}0.001 \\
(0.001)\end{array}$ & $\begin{array}{c}0.001 \\
(0.001)\end{array}$ & $\begin{array}{c}0.001 \\
(0.001)\end{array}$ & $\begin{array}{c}0.000 \\
(0.000)\end{array}$ \\
\hline Liquidity ratio & $\begin{array}{l}-1.764 \\
(2.847)\end{array}$ & $\begin{array}{l}-1.640 \\
(2.589)\end{array}$ & $\begin{array}{c}-1.522 * * \\
(0.690)\end{array}$ & $\begin{array}{c}-1.532 * * \\
(0.629)\end{array}$ & $\begin{array}{c}-1.504^{* *} \\
(0.758)\end{array}$ & $\begin{array}{c}-1.628^{* *} \\
(0.762)\end{array}$ \\
\hline SIZE & $\begin{array}{c}-0.668^{* *} \\
(0.263)\end{array}$ & $\begin{array}{c}-1.267^{* * *} \\
(0.460)\end{array}$ & $\begin{array}{c}0.621^{* * *} \\
(0.123)\end{array}$ & $\begin{array}{c}0.287 * * \\
(0.133)\end{array}$ & $\begin{array}{c}0.591 * * * \\
(0.132)\end{array}$ & $\begin{array}{c}0.546^{* * *} \\
(0.140)\end{array}$ \\
\hline Regulation & $\begin{array}{c}-0.007^{* * *} \\
(0.002)\end{array}$ & $\begin{array}{c}-25.35^{* *} \\
(12.04)\end{array}$ & $\begin{array}{c}1.958^{* * *} \\
(0.308)\end{array}$ & $\begin{array}{c}-8.597^{* * *} \\
(1.797)\end{array}$ & $\begin{array}{l}0.271^{* * *} \\
(0.0945)\end{array}$ & $\begin{array}{c}-4.564^{* * *} \\
(1.279)\end{array}$ \\
\hline $\begin{array}{c}\text { Regulation*Total } \\
\text { Asset }\end{array}$ & & $1.197^{* *}$ & & $0.745^{* * *}$ & & $0.34^{* * *}$ \\
\hline Constant & $\begin{array}{c}28.89 * * * \\
(6.760)\end{array}$ & $\begin{array}{c}(0.580) \\
41.43^{* * *} \\
(10.32)\end{array}$ & $\begin{array}{c}-6.654^{* * *} \\
(1.803)\end{array}$ & $\begin{array}{l}(0.126) \\
-1.856 \\
(1.960)\end{array}$ & $\begin{array}{c}-4.263 * * \\
(1.955)\end{array}$ & $\begin{array}{c}(0.091) \\
-3.576^{*} \\
(2.067)\end{array}$ \\
\hline $\begin{array}{l}\text { Number of obs. } \\
\text { R-squared }\end{array}$ & $\begin{array}{c}78 \\
0.459\end{array}$ & $\begin{array}{c}78 \\
0.546\end{array}$ & $\begin{array}{c}578 \\
0.471\end{array}$ & $\begin{array}{c}578 \\
0.618\end{array}$ & $\begin{array}{c}578 \\
0.376\end{array}$ & $\begin{array}{c}578 \\
0.427\end{array}$ \\
\hline
\end{tabular}

\section{Robustness Check}

To check the robustness of our main findings, we verified that outliers do not affect our results (and the conclusions in terms of hypotheses verification). We did this by using unbalanced panel data. We report our results in Appendices A-F, which provide verification of Tables $2-7$, respectively. We found that the regression results are consistent with our main findings. Nevertheless, we proved that the estimations based on unbalanced panels are as reliable as those based on balanced ones (Arellano 2003).

\section{Conclusions}

The BL has been introduced in nearly all European countries. The main aim of the BL introduction was to change the incentives of banks' management and owners to contribute to systemic risk. However, researchers and experts have also noticed a negative impact of the $\mathrm{BL}$, as it may increase financial transaction costs; reduce the number of transactions and lower transactions value, which can negatively affect bank liquidity; and result in wider interest spreads and higher volatility, as well as a rise in prices of banking services (Huizinga et al. 2012; Kolesnika and Dovladbekova 2014). On the other hand, researchers have proven that the bank levy might not decrease banks' profitability, because costs are shifted to customers, or some financial transactions can be transferred to countries in which such taxes do not exist (Albertazzi and Gambacorta 2010; Huizinga et al. 2012).

This paper empirically investigated the effects of the BL on the profitability of Hungarian and German banks during the period of 2005-2015. The results document that the effect of the BL on financial sector performance depends on the bank's size. Evidence suggests that, in general, the BL negatively affects the ROA ratio of the financial sector. It cannot be concluded that the introduction of the BL has significantly affected the lending activity or the volume of customer deposits in commercial banks. Moreover, we conclude that financial institutions might try to shift their activities among different locations or entities or restructure their balance sheet to decrease the bank levy. Moreover, our results indicate that, in Hungarian commercial banks, the value of the paid bank levy decreased after the 
Basel III introduction. On the other hand, the result shows that, in German commercial banks, the value of the paid bank levy increased after the Basel III and SRF introduction, especially in larger banks.

This study has some limitations. We only examined the effect of passing through the bank levy within the group and to customers, but there might be other possible approaches to passing through the levy. In future studies, it might be necessary to capture other scenarios for passing through the bank levy, for example, benefiting from securities market capabilities that operate in selected countries. The question is whether the well-developed securities market extend the ability of banks to avoid levies.

The empirical findings of this study have several implications for policy makers. This evidence contributes to the current debate regarding the potential effects of BLs on the financial sector's function in the future.

Funding: This research was funded by National Science Center, Poland, grant number UMO2017/25/N/HS4/01912 and The APC was funded by Kozminski University.

Institutional Review Board Statement: Not applicable.

Informed Consent Statement: Not applicable.

Data Availability Statement: The data presented in this study are available on request from the corresponding author. The data are not publicly available due to agreement with data provider.

Conflicts of Interest: The authors declare no conflict of interest.

\section{Appendix A}

Table A1. Data presenting estimates based on GLS regressions with a random effect on Hungarian commercial banks. Symbols $* * *$, and ${ }^{* * *}$ represent statistical significance at the levels of $10 \%, 5 \%$, and $1 \%$, respectively.

\begin{tabular}{|c|c|c|c|c|c|c|}
\hline & \multicolumn{6}{|c|}{ Commercial Banks } \\
\hline & $\begin{array}{l}\text { Profit before Tax } \\
\text { (ln) }\end{array}$ & $\begin{array}{l}\text { Profit before Tax } \\
\text { (ln) }\end{array}$ & $\begin{array}{l}\text { Profit before Tax } \\
\text { to Total Assets }\end{array}$ & $\begin{array}{l}\text { Profit before Tax } \\
\text { to Total Assets }\end{array}$ & Return on Assets & Return on Assets \\
\hline VARIABLES & (1) & (2) & (3) & (4) & (5) & (6) \\
\hline \multirow[t]{2}{*}{ Efficiency } & 0.001 & 0.001 & 0.001 & 0.001 & 0.001 & -0.001 \\
\hline & $(0.002)$ & $(0.002)$ & $(0.001)$ & $(0.001)$ & $(0.001)$ & $(0.002)$ \\
\hline \multirow[t]{2}{*}{ GDP growth } & 0.407 & 0.440 & $0.022 * * *$ & $0.021^{* * *}$ & $1.887^{* * *}$ & $1.816^{* * *}$ \\
\hline & $(0.599)$ & $(0.596)$ & $(0.007)$ & $(0.007)$ & $(0.633)$ & $(0.672)$ \\
\hline \multirow[t]{2}{*}{ Inflation } & 0.277 & 0.345 & $0.021 * * *$ & $0.020 * * *$ & $1.863^{* * *}$ & $1.775^{* *}$ \\
\hline & $(0.506)$ & $(0.489)$ & $(0.007)$ & $(0.007)$ & $(0.684)$ & $(0.721)$ \\
\hline \multirow[t]{2}{*}{ Capital Ratio } & -0.072 & -0.078 & 0.001 & 0.001 & 0.033 & 0.049 \\
\hline & $(0.059)$ & $(0.059)$ & $(0.001)$ & $(0.001)$ & $(0.098)$ & $(0.100)$ \\
\hline \multirow[t]{2}{*}{ Credit Risk } & 0.001 & 0.001 & 0.001 & 0.001 & -0.001 & 0.001 \\
\hline & $(0.001)$ & $(0.001)$ & $(0.001)$ & $(0.001)$ & $(0.001)$ & $(0.001)$ \\
\hline \multirow[t]{2}{*}{ Liquidity ratio } & -2.867 & $-3.067^{*}$ & 0.030 & 0.027 & 2.777 & 2.309 \\
\hline & $(1.853)$ & $(1.785)$ & $(0.026)$ & $(0.028)$ & $(2.483)$ & $(2.740)$ \\
\hline \multirow[t]{2}{*}{ SIZE } & -0.006 & 0.171 & -0.001 & -0.002 & -0.061 & -0.183 \\
\hline & $(0.253)$ & $(0.143)$ & $(0.001)$ & $(0.002)$ & $(0.145)$ & $(0.249)$ \\
\hline \multirow[t]{2}{*}{ BL } & 0.755 & 0.451 & 0.049 & 0.051 & 4.488 & 4.653 \\
\hline & $(1.641)$ & $(1.637)$ & $(0.033)$ & $(0.033)$ & $(3.389)$ & $(3.348)$ \\
\hline \multirow[t]{2}{*}{ BL ${ }^{*}$ Total Asset } & & $0.001 * *$ & & 0.001 & & -0.001 \\
\hline & & $(0.001)$ & & $(0.001)$ & & $(0.001)$ \\
\hline \multirow[t]{2}{*}{ Constant } & $14.140 * *$ & 10.670 ** & -0.124 * & $-0.099 *$ & -10.950 & -8.112 \\
\hline & $(6.563)$ & $(4.569)$ & $(0.070)$ & $(0.084)$ & $(7.292)$ & $(8.973)$ \\
\hline Number of obs. & 97 & 97 & 107 & 107 & 107 & 107 \\
\hline R-squared & 0.498 & 0.793 & 0.144 & 0.088 & 0.169 & 0.098 \\
\hline
\end{tabular}




\section{Appendix B}

Table A2. Data presenting estimates based on GLS regressions with a random effect on all Hungarian commercial banks. Symbols ${ }^{* *}$, and ${ }^{* * *}$ represent statistical significance at the levels of $10 \%, 5 \%$, and $1 \%$, respectively.

\begin{tabular}{|c|c|c|c|c|c|c|}
\hline \multirow[b]{3}{*}{ VARIABLES } & \multicolumn{6}{|c|}{ All Hungarian Commercial Banks } \\
\hline & \multicolumn{2}{|c|}{ Loans Growth } & \multicolumn{2}{|c|}{ Loans to Total Asset } & \multicolumn{2}{|c|}{ Loans (ln) } \\
\hline & (1) & (2) & (3) & (4) & (5) & (6) \\
\hline Efficiency & $\begin{array}{l}-1.680 \\
(2.152)\end{array}$ & $\begin{array}{l}-1.674 \\
(2.059)\end{array}$ & $\begin{array}{c}-0.482 * * * \\
(0.455)\end{array}$ & $\begin{array}{c}-0.458 \text { ** } \\
(0.447)\end{array}$ & $\begin{array}{l}-0.550 \\
(1.590)\end{array}$ & $\begin{array}{l}-0.001 \\
(0.001)\end{array}$ \\
\hline GDP Growth & $\begin{array}{c}0.080 \\
(0.072)\end{array}$ & $\begin{array}{l}0.065 \\
(0.072)\end{array}$ & $\begin{array}{c}0.025 \\
(0.030)\end{array}$ & $\begin{array}{c}0.022 \\
(0.029)\end{array}$ & $\begin{array}{l}-0.057 \\
(0.083)\end{array}$ & $\begin{array}{c}0.025 \\
(0.075)\end{array}$ \\
\hline Inflation & $\begin{array}{c}0.048 \\
(0.060)\end{array}$ & $\begin{array}{l}0.056 \\
(0.061)\end{array}$ & $\begin{array}{c}0.014 \\
(0.028)\end{array}$ & $\begin{array}{c}0.009 \\
(0.028)\end{array}$ & $\begin{array}{l}-0.138 \\
(0.112)\end{array}$ & $\begin{array}{l}-0.008 \\
(0.084)\end{array}$ \\
\hline Capital Ratio & $\begin{array}{c}0.003 \\
(0.003)\end{array}$ & $\begin{array}{l}0.003 * \\
(0.003)\end{array}$ & $\begin{array}{l}-0.003 \\
(0.002)\end{array}$ & $\begin{array}{l}-0.002 \\
(0.002)\end{array}$ & $\begin{array}{c}0.001 \\
(0.010)\end{array}$ & $\begin{array}{l}-0.017 \\
(0.010)\end{array}$ \\
\hline Credit Risk & $\begin{array}{l}-0.382 \\
(0.586)\end{array}$ & $\begin{array}{c}0.235 \\
(0.199)\end{array}$ & $\begin{array}{l}-0.048 \\
(0.110)\end{array}$ & $\begin{array}{l}-0.067 \\
(0.115)\end{array}$ & $\begin{array}{l}-0.242 \\
(0.598)\end{array}$ & $\begin{array}{l}-0.502 \\
(1.523)\end{array}$ \\
\hline Liquidity Ratio & $\begin{array}{c}0.001 \\
(0.001)\end{array}$ & $\begin{array}{c}0.001 \\
(0.001)\end{array}$ & $\begin{array}{c}0.001 \\
(0.001)\end{array}$ & $\begin{array}{l}0.001 \\
(0.001)\end{array}$ & $\begin{array}{l}-0.001 \\
(0.001)\end{array}$ & $\begin{array}{l}-0.260 \\
(0.386)\end{array}$ \\
\hline SIZE & $\begin{array}{l}0.052 * \\
(0.032)\end{array}$ & $\begin{array}{c}0.041 \\
(0.035)\end{array}$ & $\begin{array}{l}0.021^{*} \\
(0.012)\end{array}$ & $\begin{array}{c}0.025^{* *} \\
(0.013)\end{array}$ & $\begin{array}{c}0.263 \\
(0.287)\end{array}$ & $\begin{array}{c}0.138 \\
(0.152)\end{array}$ \\
\hline BL & $\begin{array}{l}-0.682 \\
(0.503)\end{array}$ & $\begin{array}{c}0.229 * * * \\
(0.949)\end{array}$ & $\begin{array}{l}-0.195 \\
(0.207)\end{array}$ & $\begin{array}{c}0.306 \\
(0.380)\end{array}$ & $\begin{array}{c}0.614 \\
(0.654)\end{array}$ & $\begin{array}{l}-12.296 \\
(3.101)\end{array}$ \\
\hline BL*Total Asset & & $\begin{array}{c}-0.039 * * * \\
(0.044)\end{array}$ & & $\begin{array}{c}-0.024 \text { * } \\
(0.015)\end{array}$ & & $\begin{array}{c}0.632 \\
(0.163)\end{array}$ \\
\hline Constant & $\begin{array}{c}1.190 \\
(3.022)\end{array}$ & $\begin{array}{c}1.026^{* * *} \\
(1.665)\end{array}$ & $\begin{array}{c}0.428 * * * \\
(0.154)\end{array}$ & $\begin{array}{c}0.020 * * * \\
(0.030)\end{array}$ & $\begin{array}{c}2.030 * * * \\
(1.067)\end{array}$ & $\begin{array}{c}3.153^{* * *} \\
(0.297)\end{array}$ \\
\hline $\begin{array}{c}\text { Number of obs. } \\
\text { R-squared }\end{array}$ & $\begin{array}{c}95 \\
0.432\end{array}$ & $\begin{array}{c}95 \\
0.496\end{array}$ & $\begin{array}{c}107 \\
0.007\end{array}$ & $\begin{array}{c}107 \\
0.006\end{array}$ & $\begin{array}{c}107 \\
0.055\end{array}$ & $\begin{array}{c}107 \\
0.839\end{array}$ \\
\hline
\end{tabular}

\section{Appendix C}

Table A3. Data presenting estimates based on GLS regressions with a random effect on Hungarian commercial banks. Symbols ***, and ${ }^{* * *}$ represent statistical significance at the levels of $10 \%, 5 \%$, and $1 \%$, respectively.

\begin{tabular}{|c|c|c|c|c|}
\hline \multirow[b]{3}{*}{ VARIABLES } & \multicolumn{4}{|c|}{ Commercial Hungarian Banks } \\
\hline & \multicolumn{2}{|c|}{ Other Earning Asset to Total Assets } & \multicolumn{2}{|c|}{ Other Earning Assets (ln) } \\
\hline & (1) & (2) & (3) & (4) \\
\hline Efficiency & $\begin{array}{c}0.001 \text { *** } \\
(0.001)\end{array}$ & $\begin{array}{l}0.001 \text { * } \\
(0.001)\end{array}$ & $\begin{array}{c}-0.001 \text { * } \\
(0.001)\end{array}$ & $\begin{array}{c}-0.001 \text { ** } \\
(0.001)\end{array}$ \\
\hline GDP Growth & $\begin{array}{c}0.032 \\
(0.054)\end{array}$ & $\begin{array}{c}0.036 \\
(0.054)\end{array}$ & $\begin{array}{c}-0.184 \\
(0.255)\end{array}$ & $\begin{array}{c}-0.084 \\
(0.227)\end{array}$ \\
\hline Inflation & $\begin{array}{c}0.044 \\
(0.052)\end{array}$ & $\begin{array}{c}0.048 \\
(0.053)\end{array}$ & $\begin{array}{l}-0.225 \\
(0.261)\end{array}$ & $\begin{array}{l}-0.099 \\
(0.243)\end{array}$ \\
\hline Capital Ratio & $\begin{array}{c}0.002 \\
(0.002)\end{array}$ & $\begin{array}{c}0.001 \\
(0.002)\end{array}$ & $\begin{array}{c}0.014 \\
(0.011)\end{array}$ & $\begin{array}{l}-0.001 \\
(0.013)\end{array}$ \\
\hline Credit Risk & $\begin{array}{c}0.500 \\
(0.404)\end{array}$ & $\begin{array}{c}0.472 \\
(0.392)\end{array}$ & $\begin{array}{c}1.730 \\
(1.170)\end{array}$ & $\begin{array}{c}1.221 \\
(1.249)\end{array}$ \\
\hline Liquidity Ratio & $\begin{array}{l}-0.035 \\
(0.103)\end{array}$ & $\begin{array}{l}-0.014 \\
(0.100)\end{array}$ & $\begin{array}{c}1.730 \\
(1.168)\end{array}$ & $\begin{array}{l}-0.015 \\
(0.638)\end{array}$ \\
\hline SIZE & $\begin{array}{c}-0.019 \text { ** } \\
(0.009)\end{array}$ & $\begin{array}{c}-0.024 \text { ** } \\
(0.011)\end{array}$ & $\begin{array}{l}-0.009 \\
(0.249)\end{array}$ & $\begin{array}{c}0.057 \\
(0.218)\end{array}$ \\
\hline BL & $\begin{array}{l}-0.118 \\
(0.353)\end{array}$ & $\begin{array}{c}-0.678 * \\
(0.409)\end{array}$ & $\begin{array}{c}1.910 \\
(1.723)\end{array}$ & $\begin{array}{c}-7.183^{* *} \\
(3.936)\end{array}$ \\
\hline BL*Total Asset & & $\begin{array}{c}0.027^{* *} \\
(0.013)\end{array}$ & & $\begin{array}{c}0.426^{* * *} \\
(0.196)\end{array}$ \\
\hline Constant & $\begin{array}{c}1.443 \\
(0.647)\end{array}$ & $\begin{array}{l}1.844^{*} \\
(0.716)\end{array}$ & $\begin{array}{l}0.734^{*} \\
(0.797)\end{array}$ & $\begin{array}{c}3.161 \\
(11.83)\end{array}$ \\
\hline Number of obs. & 107 & 107 & 107 & 107 \\
\hline R-squared & 0.005 & 0.042 & 0.013 & 0.712 \\
\hline
\end{tabular}




\section{Appendix D}

Table A4. Data presenting estimates based on GLS regressions with a random effect on German commercial banks. Symbols $*, * *$, and ${ }^{* * *}$ represent statistical significance at the levels of $10 \%, 5 \%$, and $1 \%$, respectively.

\begin{tabular}{|c|c|c|c|c|c|c|}
\hline \multirow[b]{3}{*}{ VARIABLES } & \multicolumn{6}{|c|}{ Commercial banks } \\
\hline & \multicolumn{2}{|c|}{ Profit before Tax (ln) } & \multicolumn{2}{|c|}{ Profit before Tax to Total Assets (\%) } & \multicolumn{2}{|c|}{ Return on Assets } \\
\hline & (1) & (2) & (3) & (4) & (5) & (6) \\
\hline Efficiency & $\begin{array}{l}-0.396 \\
(0.265)\end{array}$ & $\begin{array}{l}-0.002 \\
(0.003)\end{array}$ & $\begin{array}{l}-0.010 \\
(0.058)\end{array}$ & $\begin{array}{l}-0.001 \\
(0.001)\end{array}$ & $\begin{array}{l}2.544 \text { * } \\
(1.531)\end{array}$ & $\begin{array}{c}0.007 \\
(0.007)\end{array}$ \\
\hline GDP growth & $\begin{array}{l}-1.203 \\
(0.836)\end{array}$ & $\begin{array}{l}-0.978 \\
(0.891)\end{array}$ & $\begin{array}{l}-0.262 \\
(0.287)\end{array}$ & $\begin{array}{l}-0.163 \\
(0.318)\end{array}$ & $\begin{array}{l}-0.944 \\
(2.183)\end{array}$ & $\begin{array}{l}-0.111 \\
(0.378)\end{array}$ \\
\hline Inflation & $\begin{array}{l}-1.592 \\
(1.007)\end{array}$ & $\begin{array}{l}-1.288 \\
(1.062)\end{array}$ & $\begin{array}{l}-0.330 \\
(0.340)\end{array}$ & $\begin{array}{l}-0.194 \\
(0.374)\end{array}$ & $\begin{array}{l}-1.084 \\
(2.734)\end{array}$ & $\begin{array}{l}-0.117 \\
(0.245)\end{array}$ \\
\hline Capital Ratio & $\begin{array}{l}-1.121 \\
(1.338)\end{array}$ & $\begin{array}{l}-1.005 \\
(1.261)\end{array}$ & $\begin{array}{l}-0.392 \\
(0.260)\end{array}$ & $\begin{array}{l}-0.387 \\
(0.262)\end{array}$ & $\begin{array}{c}-7.450 \text { * } \\
(3.842)\end{array}$ & $\begin{array}{l}-2.448 \\
(2.624)\end{array}$ \\
\hline Credit Risk & $\begin{array}{c}-0.001 \\
(0.001)\end{array}$ & $\begin{array}{c}-0.001 \\
(0.001)\end{array}$ & $\begin{array}{c}0.001 \\
(0.001)\end{array}$ & $\begin{array}{l}-0.001 \\
(0.001)\end{array}$ & $\begin{array}{l}-0.001 \\
(0.001)\end{array}$ & $\begin{array}{c}0.001 \\
(0.001)\end{array}$ \\
\hline Liquidity ratio & $\begin{array}{c}-1.549^{* * *} \\
(0.469)\end{array}$ & $\begin{array}{c}-1.507^{* * *} \\
(0.519)\end{array}$ & $\begin{array}{c}-0.219 \text { * } \\
(0.126)\end{array}$ & $\begin{array}{c}-0.231^{* *} \\
(0.116)\end{array}$ & $\begin{array}{c}4.658 \\
(4.923)\end{array}$ & $\begin{array}{l}-1.616 \\
(1.071)\end{array}$ \\
\hline SIZE & $\begin{array}{c}0.396^{* * *} \\
(0.073)\end{array}$ & $\begin{array}{c}0.462 * * * \\
(0.079)\end{array}$ & $\begin{array}{c}0.005 \\
(0.021)\end{array}$ & $\begin{array}{c}0.005 \\
(0.017)\end{array}$ & $\begin{array}{c}0.016 \\
(0.507)\end{array}$ & $\begin{array}{c}0.325 \\
(0.336)\end{array}$ \\
\hline BL & $\begin{array}{l}-0.559 \\
(0.464)\end{array}$ & $\begin{array}{l}-0.417 \\
(0.486)\end{array}$ & $\begin{array}{l}-0.147 \\
(0.143)\end{array}$ & $\begin{array}{l}-0.097 \\
(0.133)\end{array}$ & $\begin{array}{c}-8.972 * \\
(4.880)\end{array}$ & $\begin{array}{c}-3.810^{* * *} \\
(1.476)\end{array}$ \\
\hline $\begin{array}{l}\text { BL*Relevant } \\
\text { Liabilities }\end{array}$ & & $\begin{array}{c}-0.001^{* * *} \\
(0.001)\end{array}$ & & $\begin{array}{c}-0.001 \text { * } \\
(0.001)\end{array}$ & & $\begin{array}{l}-0.001 \\
(0.001)\end{array}$ \\
\hline Constant & $\begin{array}{c}6.752^{* * * *} \\
(2.320)\end{array}$ & $\begin{array}{c}5.013 * * \\
(2.439)\end{array}$ & $\begin{array}{c}0.995 \\
(0.697)\end{array}$ & $\begin{array}{c}0.887 \\
(0.760)\end{array}$ & $\begin{array}{c}9.064 \\
(9.221)\end{array}$ & $\begin{array}{l}-0.417 \\
(5.173)\end{array}$ \\
\hline $\begin{array}{l}\text { Number of obs. } \\
\text { R-squared }\end{array}$ & $\begin{array}{c}561 \\
0.542\end{array}$ & $\begin{array}{c}555 \\
0.597\end{array}$ & $\begin{array}{c}616 \\
0.001\end{array}$ & $\begin{array}{c}607 \\
0.006\end{array}$ & $\begin{array}{c}691 \\
0.273\end{array}$ & $\begin{array}{c}607 \\
0.182\end{array}$ \\
\hline
\end{tabular}

\section{Appendix E}

Table A5. Data presenting estimates based on GLS regressions with a random effect on all German commercial banks. Symbols $* * *$, and ${ }^{* * *}$ represent statistical significance at the levels of $10 \%, 5 \%$, and $1 \%$, respectively.

\begin{tabular}{|c|c|c|c|c|c|c|}
\hline & \multicolumn{6}{|c|}{ Commercial Banks } \\
\hline & Loan Growth & Loan Growth & Loan to Assets & Loan to Assets & Loan $(\ln )$ & Loan $(\ln )$ \\
\hline VARIABLES & (1) & (2) & (3) & (4) & (5) & (6) \\
\hline Efficiency & $\begin{array}{l}-4.625 \\
(6.534)\end{array}$ & $\begin{array}{c}0.015 \\
(0.013)\end{array}$ & $\begin{array}{c}0.019 \\
(0.024)\end{array}$ & $\begin{array}{c}-0.001^{* * *} \\
(0.0004)\end{array}$ & $\begin{array}{c}0.027 \\
(0.148)\end{array}$ & $\begin{array}{l}-0.001 \\
(0.001)\end{array}$ \\
\hline GDP Growth & $\begin{array}{c}0.153 \\
(3.675)\end{array}$ & $\begin{array}{l}-0.133 \\
(0.167)\end{array}$ & $\begin{array}{l}-0.083 \\
(0.055)\end{array}$ & $\begin{array}{l}-0.001 \\
(0.002)\end{array}$ & $\begin{array}{l}-0.419 \\
(0.275)\end{array}$ & $\begin{array}{c}0.005 \\
(0.007)\end{array}$ \\
\hline Inflation & $\begin{array}{l}-0.060 \\
(4.848)\end{array}$ & $\begin{array}{c}0.535 \\
(0.487)\end{array}$ & $\begin{array}{l}-0.099 \\
(0.067)\end{array}$ & $\begin{array}{c}0.018 \text { ** } \\
(0.008)\end{array}$ & $\begin{array}{l}-0.517 \\
(0.338)\end{array}$ & $\begin{array}{l}-0.001 \\
(0.021)\end{array}$ \\
\hline Capital Ratio & $\begin{array}{l}-5.751 \\
(8.953)\end{array}$ & $\begin{array}{l}-6.109 \\
(4.714)\end{array}$ & $\begin{array}{c}0.166 \\
(0.182)\end{array}$ & $\begin{array}{l}-0.203 \\
(0.177)\end{array}$ & $\begin{array}{l}-0.536 \\
(1.109)\end{array}$ & $\begin{array}{c}-1.590 \text { * } \\
(0.946)\end{array}$ \\
\hline Credit Risk & $\begin{array}{c}0.001 \\
(0.001)\end{array}$ & $\begin{array}{l}-0.001 \\
(0.001)\end{array}$ & $\begin{array}{l}-0.001 \\
(0.001)\end{array}$ & $\begin{array}{l}-0.001 \\
(0.001)\end{array}$ & $\begin{array}{l}-0.001 \\
(0.001)\end{array}$ & $\begin{array}{l}-0.001 \\
(0.001)\end{array}$ \\
\hline Liquidity Ratio & $\begin{array}{l}-0.262 \\
(2.960)\end{array}$ & $\begin{array}{c}-4.128 \\
(2.747)\end{array}$ & $\begin{array}{c}-0.206^{* * *} \\
(0.056)\end{array}$ & $\begin{array}{c}-0.157^{* *} \\
(0.072)\end{array}$ & $\begin{array}{c}-0.791 \text { ** } \\
(0.309)\end{array}$ & $\begin{array}{l}-0.604 \\
(0.379)\end{array}$ \\
\hline SIZE & $\begin{array}{l}-0.965 \\
(0.588)\end{array}$ & $\begin{array}{c}-0.898 * * * \\
(0.311)\end{array}$ & $\begin{array}{c}-0.003 \\
(0.005)\end{array}$ & $\begin{array}{c}-0.010 \\
(0.008)\end{array}$ & $\begin{array}{c}0.027 \\
(0.048)\end{array}$ & $\begin{array}{c}0.031 \\
(0.052)\end{array}$ \\
\hline BL & $\begin{array}{c}-24.970 \\
(19.10)\end{array}$ & $\begin{array}{l}-2.326 \\
(1.551)\end{array}$ & $\begin{array}{c}0.021 \\
(0.043)\end{array}$ & $\begin{array}{c}0.018 \\
(0.018)\end{array}$ & $\begin{array}{l}-0.011 \\
(0.176)\end{array}$ & $\begin{array}{c}-0.0488 \\
(0.101)\end{array}$ \\
\hline $\begin{array}{l}\text { BL*Relevant } \\
\text { Liabilities }\end{array}$ & & $\begin{array}{c}0.001^{* * *} \\
(0.001)\end{array}$ & & $\begin{array}{l}-0.001 \\
(0.001)\end{array}$ & & $\begin{array}{c}0.001 \text { ** } \\
(0.001)\end{array}$ \\
\hline Constant & $\begin{array}{l}42.490 \\
(37.22)\end{array}$ & $\begin{array}{c}15.26^{* * *} \\
(5.665)\end{array}$ & $\begin{array}{c}0.788^{* * *} \\
(0.154)\end{array}$ & $\begin{array}{c}0.720 * * * \\
(0.130)\end{array}$ & $\begin{array}{c}14.230^{* * * *} \\
(1.067)\end{array}$ & $\begin{array}{c}13.53^{* * *} \\
(0.797)\end{array}$ \\
\hline $\begin{array}{l}\text { Number of obs. } \\
\text { R-squared }\end{array}$ & $\begin{array}{c}610 \\
0.009\end{array}$ & $\begin{array}{c}603 \\
0.631\end{array}$ & $\begin{array}{c}614 \\
0.001\end{array}$ & $\begin{array}{c}607 \\
0.204\end{array}$ & $\begin{array}{c}612 \\
0.273\end{array}$ & $\begin{array}{c}605 \\
0.283\end{array}$ \\
\hline
\end{tabular}




\section{Appendix F}

Table A6. Data presenting estimates based on GLS regressions with a random effect on all German commercial banks. Symbols ***, and ** represent statistical significance at the levels of $10 \%, 5 \%$, and $1 \%$, respectively.

\begin{tabular}{|c|c|c|c|c|c|c|}
\hline & \multicolumn{6}{|c|}{ Commercial Banks } \\
\hline & $\begin{array}{l}\text { Deposit } \\
\text { Growth }\end{array}$ & $\begin{array}{l}\text { Deposit } \\
\text { Growth }\end{array}$ & $\begin{array}{l}\text { Deposit to } \\
\text { Assets }\end{array}$ & $\begin{array}{l}\text { Deposit to } \\
\text { Assets }\end{array}$ & Deposit (ln) & Deposit (ln) \\
\hline VARIABLES & (1) & (2) & (3) & (4) & (5) & (6) \\
\hline Efficiency & $\begin{array}{l}24.120 \\
(16.12)\end{array}$ & $\begin{array}{c}0.058 \\
(0.047)\end{array}$ & $\begin{array}{l}0.031 \text { * } \\
(0.017)\end{array}$ & $\begin{array}{l}0.001 * \\
(0.001)\end{array}$ & $\begin{array}{l}-0.078 \\
(0.151)\end{array}$ & $\begin{array}{c}0.001 \\
(0.001)\end{array}$ \\
\hline GDP Growth & $\begin{array}{l}-3.882 \\
(18.01)\end{array}$ & $\begin{array}{c}0.217 \\
(0.601)\end{array}$ & $\begin{array}{c}-0.134 \text { * } \\
(0.080)\end{array}$ & $\begin{array}{l}-0.002 \\
(0.001)\end{array}$ & $\begin{array}{l}-0.626 \\
(0.437)\end{array}$ & $\begin{array}{c}0.004 \\
(0.011)\end{array}$ \\
\hline Inflation & $\begin{array}{c}-3.701 \\
(21.270)\end{array}$ & $\begin{array}{l}-1.722 \\
(1.387)\end{array}$ & $\begin{array}{c}-0.166^{*} \\
(0.096)\end{array}$ & $\begin{array}{l}-0.009 \\
(0.006)\end{array}$ & $\begin{array}{c}-0.712 \\
(0.525)\end{array}$ & $\begin{array}{c}0.019 \\
(0.026)\end{array}$ \\
\hline Capital Ratio & $\begin{array}{l}-66.840 \\
(111.600)\end{array}$ & $\begin{array}{c}-178.100 * \\
(100.5)\end{array}$ & $\begin{array}{l}-0.100 \\
(0.080)\end{array}$ & $\begin{array}{l}-0.093 \\
(0.119)\end{array}$ & $\begin{array}{l}-1.044 \\
(0.788)\end{array}$ & $\begin{array}{l}-0.375 \\
(0.481)\end{array}$ \\
\hline Credit Risk & $\begin{array}{c}0.001 \\
(0.001)\end{array}$ & $\begin{array}{l}-0.001 \\
(0.001)\end{array}$ & $\begin{array}{c}0.001 \\
(0.001)\end{array}$ & $\begin{array}{c}0.001 \\
(0.001)\end{array}$ & $\begin{array}{c}0.001 \\
(0.001)\end{array}$ & $\begin{array}{c}0.001 \\
(0.001)\end{array}$ \\
\hline Liquidity Ratio & $\begin{array}{l}53.890 * \\
(30.020)\end{array}$ & $\begin{array}{l}73.040 * * \\
(30.100)\end{array}$ & $\begin{array}{c}0.029 \\
(0.049)\end{array}$ & $\begin{array}{c}0.052 \\
(0.056)\end{array}$ & $\begin{array}{l}-0.509 \\
(0.367)\end{array}$ & $\begin{array}{l}-0.203 \\
(0.153)\end{array}$ \\
\hline SIZE & $\begin{array}{l}19.690 * \\
(11.940)\end{array}$ & $\begin{array}{c}5.642 \\
(4.040)\end{array}$ & $\begin{array}{l}-0.003 \\
(0.005)\end{array}$ & $\begin{array}{l}-0.001 \\
(0.005)\end{array}$ & $\begin{array}{c}0.162^{* * *} \\
(0.045)\end{array}$ & $\begin{array}{c}0.183^{* * *} \\
(0.049)\end{array}$ \\
\hline $\mathrm{BL}$ & $\begin{array}{c}38.150 \\
(24.850)\end{array}$ & $\begin{array}{c}9.896 \\
(7.908)\end{array}$ & $\begin{array}{c}0.040 \\
(0.035)\end{array}$ & $\begin{array}{c}0.032 \\
(0.023)\end{array}$ & $\begin{array}{l}-0.208 \\
(0.324)\end{array}$ & $\begin{array}{l}-0.037 \\
(0.117)\end{array}$ \\
\hline $\begin{array}{c}\text { BL*Relevant } \\
\text { Liabilities }\end{array}$ & & $\begin{array}{l}-0.001 \\
(0.001)\end{array}$ & & $\begin{array}{l}-0.001 \\
(0.001)\end{array}$ & & $\begin{array}{c}0.001 \\
(0.001)\end{array}$ \\
\hline Constant & $\begin{array}{l}-399.900 * \\
(222.200)\end{array}$ & $\begin{array}{c}-153.8 \\
(103.100)\end{array}$ & $\begin{array}{c}0.943^{* * *} \\
(0.189)\end{array}$ & $\begin{array}{c}0.641^{* * *} \\
(0.088)\end{array}$ & $\begin{array}{c}13.230^{* * *} \\
(1.425)\end{array}$ & $\begin{array}{c}11.210^{* * * *} \\
(0.718)\end{array}$ \\
\hline $\begin{array}{l}\text { Number of obs. } \\
\text { R-squared }\end{array}$ & $\begin{array}{c}603 \\
0.002\end{array}$ & $\begin{array}{c}602 \\
0.879\end{array}$ & $\begin{array}{c}608 \\
0.114\end{array}$ & $\begin{array}{c}607 \\
0.034\end{array}$ & $\begin{array}{c}605 \\
0.413\end{array}$ & $\begin{array}{c}604 \\
0.446\end{array}$ \\
\hline
\end{tabular}

\section{References}

Albertazzi, Ugo, and Leonardo Gambacorta. 2010. Bank profitability and taxation. Journal of Banking E Finance 34: $2801-810$.

Allen, Franklin, Elena Carletti, and Robert Marquez. 2011. Credit market competition and capital regulation. The Review of Financial Studies 24: 983-1018. [CrossRef]

Altunbas, Yener, Simone Manganelli, and David Marques-Ibanez. 2011. Bank Risk during the Financial Crisis: Do Business Models Matter? ECB Working Paper Series; Frankfurt: European Central Bank.

Andrle, Michal, Vladimír Tomšík, and Jan Vlcek. 2017. Banks' Adjustment to Basel III Reform: A Bank-Level Perspective for Emerging Europe. Carroll: International Monetary Fund.

Angbazo, Lazarus. 1997. Commercial bank net interest margins, default risk, interest-rate risk, and off-balance sheet banking. Journal of Banking \& Finance 21: 55-87.

Arellano, Manuel. 2003. Panel Data Econometrics. Oxford: Oxford University Press.

Arpa, Markus, Irene Giulini, Andreas Ittner, and Franz Pauer. 2001. The influence of macroeconomic developments on Austrian banks: Implications for banking supervision. BIS PapersPapers 1: 91-116.

Banking Act. 1998. Gesetz über das Kreditwesen (Kreditwesengesetz-KWG). Bundesministerium der Justiz und für Verbraucherschutz. Available online: http:/ / www.gesetze-im-internet.de/kredwg/index.html (accessed on 6 June 2021).

Borio, Claudio, Leonardo Gambacorta, and Boris Hofmann. 2017. The influence of monetary policy on bank profitability. International Finance 20: 48-63. [CrossRef]

Bourke, Philip. 1989. Concentration and other determinants of bank profitability in Europe, North America and Australia. Journal of Banking E Finance 13: 65-79.

Buch, Claudia M., Hilberg Björn, and Tonzer Lena. 2016. Taxing banks: An evaluation of the German bank levy. Journal of Banking and Finance 72: 52-66. [CrossRef]

Buch, C., Lena Tonzer, and Benjamin Weigert. 2017. Assessing the Effects of Regulatory Bank Levies. Available online: https: / / voxeu.org/article/assessing-effects-regulatory-bank-levies (accessed on 6 March 2018).

Campbell, John Y., and Kenneth A Froot. 1994. International experiences with securities transaction taxes. In The Internationalization of Equity Markets. Chicago: University of Chicago Press, pp. 277-308. 
Capelle-Blancard, Gunther, and Olena Havrylchyk. 2013. The Ability of Banks to Shift Corporate Income Taxes to Customers. Cambridge: MIT Press.

Capelle-Blancard, Gunther, and Olena Havrylchyk. 2017. Incidence of bank levy and bank market power. Review of Finance 21: 1023-46. [CrossRef]

Claessens, Stijn, Aslı Demirgüç-Kunt, and Harry Huizinga. 2001. How does foreign entry affect domestic banking markets? Journal of Banking \& Finance 25: 891-911.

Claessens, Stijn, Michael Keen, and Ceyla Pazarbasioglu. 2010. Financial Sector Taxation. Available online: https: / /www.imf.org/ external/np/seminars/eng/2010/paris/pdf/090110.pdf (accessed on 3 March 2018).

Committee. 2010. An Assessment of the Long-Term Economic Impact of Stronger Capital and Liquidity Requirements. Basel: Basel Committee on Banking Supervision.

D'Auria, Claudio, Antonella Foglia, and Paolo Marullo Reedtz. 1999. Bank interest rates and credit relationships in Italy. Journal of Banking E Finance 23: 1067-93.

Demirgüç-Kunt, Asli, and Harry Huizinga. 1999. Determinants of commercial bank interest margins and profitability: Some international evidence. The World Bank Economic Review 13: 379-408. [CrossRef]

Demirgüç-Kunt, Asli, and Harry Huizinga. 2001. The taxation of domestic and foreign banking. Journal of Public Economics 79: 429-53. [CrossRef]

Demirgüç-Kunt, Asli, and Harry Huizinga. 2010. Bank activity and funding strategies: The impact on risk and returns. Journal of Financial Economics 98: 626-50. [CrossRef]

Demirgüç-Kunt, Asli, Inessa Love, and Vojislav Maksimovic. 2004. Business Environment and the Incorporation Decision. Working Paper 3318. Washington, DC: World Bank, Available online: http:/ / documents.worldbank.org/curated/en/450301468780341514/pdf/ wps3317.pdf (accessed on 6 March 2018).

Devereux, Michael, John Vella, Niels Johannesen, Michael P. Devereux, Niels Johannesen, and John Vella. 2013. Can Taxes Tame the Banks? Evidence from EUROPEAN Bank Levies. Working Paper Series, WP 13/25; Oxford: Oxford University Centre for Business Taxation.

Devereux, Michael, Niels Johannesen, and John Vella. 2019. Can taxes tame the banks? Evidence from the European bank levies. The Economic Journal 129: 3058-91. [CrossRef]

DeYoung, Robert, and Gökhan Torna. 2013. Nontraditional banking activities and bank failures during the financial crisis. Journal of Financial Intermediation 22: 397-421. [CrossRef]

Díaz, Belén Díaz, Myriam García Olalla, and Sergio Sanfilippo Azofra. 2004. Bank acquisitions and performance: Evidence from a panel of European credit entities. Journal of Economics and Business 56: 377-404. [CrossRef]

Dietrich, Andreas, and Gabrielle Wanzenried. 2011. Determinants of bank profitability before and during the crisis: Evidence from Switzerland. Journal of International Financial Markets, Institutions and Money 21: 307-27. [CrossRef]

European Commission. 2010. Financial Sector Taxation. Taxation Papers, 25. Available online: https://ec.europa.eu/taxation_customs/ sites/taxation/files/resources/documents/taxation/gen_info/economic_analysis/tax_papers/taxation_paper_25_en.pdf (accessed on 6 March 2018).

Fahlenbrach, Rüdiger, Robert Prilmeier, and René M. Stulz. 2017. Why does fast loan growth predict poor performance for banks? The Review of Financial Studies 31: 1014-63. [CrossRef]

Fidrmuc, Jarko, and Ronja Lind. 2020. Macroeconomic impact of Basel III: Evidence from a meta-analysis. Journal of Banking E Finance 112: 105359.

Gambacorta, Leonardo. 2008. How do banks set interest rates? European Economic Review 52: 792-819. [CrossRef]

Gambacorta, Leonardo, and Hyun Song Shin. 2018. Why bank capital matters for monetary policy. Journal of Financial Intermediation 35: 17-29. [CrossRef]

Gilje, Erik P., Elena Loutskina, and Philip E. Strahan. 2016. Exporting liquidity: Branch banking and financial integration. The Journal of Finance 71: 1159-184. [CrossRef]

Haag, Hendrik, Steffen Jan Letto, and Hengeler Mueller. 2020. Banking regulation in Germany: Overview. Thomson Reuters. November 1. Available online: https://uk.practicallaw.thomsonreuters.com/w-007-4084?transitionType=Default\&contextData=(sc.Default) \&firstPage=true (accessed on 6 June 2021).

Haskamp, Ulrich. 2016. Spillovers of Banking Regulation: The Effect of the German Bank Levy on the Lending Rates of Regional Banks and Their Local Competitors. Ruhr Economic Papers 664: 1884-914. [CrossRef]

Hausman, Jerry A. 1978. Specification tests in econometrics. Econometrica: Journal of the Econometric Society 46: 1251-271. [CrossRef]

Hoenig, Thomas M., and Charles S. Morris. 2014. Restructuring the banking system to improve safety and soundness. In The Social Value of the Financial Sector: Too Big to Fail or Just Too Big? Singapore: World Scientific, pp. 401-25.

Houston, Joel F., and Christopher James. 1998. Do Bank Internal Capital Markets Promote Lending? Journal of Banking E Finance 22: 899-918.

Huizinga, Harry. 2004. The Taxation of Banking in an Integrating Europe. International Tax and Public Finance 11: 551-68. [CrossRef]

Huizinga, Harry, Johannes Voget, and Wolf Wagner. 2012. International Taxation and Cross-Border Banking; NBER Working Paper Series w18483; Cambridge: National Bureau of Economic Research.

International Monetary Fund. 2010. A Fair and Substantial Contribution by the Financial Sector. IMF Final Report For the G-20, June. Carroll: International Monetary Fund, pp. 2-70. 
Jiang, Wei, Kai Li, and Pei Shao. 2010. When shareholders are creditors: Effects of the simultaneous holding of equity and debt by non-commercial banking institutions. The Review of Financial Studies 23: 3595-637. [CrossRef]

Kashyap, Anil K., Jeremy C. Stein, and David W. Wilcox. 1993. Monetary Policy and Credit Conditions: Evidence from the Composition of External Finance. Amercian Economic Review 83: 78-98.

Kashyap, Anil K., Raghuram Rajan, and Jeremy C. Stein. 2002. Banks as liquidity providers: An explanation for the coexistence of lending and deposit-taking. The Journal of Finance 57: 33-73. [CrossRef]

Keen, Michael. 2011. The taxation and regulation of banks. IMF Working Paper 11: 1-38. [CrossRef]

Kogler, Michael. 2019. On the incidence of bank levies: Theory and evidence. International Tax and Public Finance 26: 677-718. [CrossRef]

Köhler, Matthias. 2015. Which banks are more risky? The impact of business models on bank stability. Journal of Financial Stability 16: 195-212. [CrossRef]

Kolesnika, Marija, and Inna Dovladbekova. 2014. Financial Transaction Tax as an Instrument for Banking Sector Regulation in the EU. Economics and Business 25: 48-53. [CrossRef]

Kumar, Vijay, and Ron Bird. 2020. Do Profitable Banks Make a Positive Contribution to the Economy? Journal of Risk and Financial Management 13: 159. [CrossRef]

Mara, Eugenia-Ramona. 2012. Taxation of Financial Sector After the Crisis in The European Union. Annals of the University of Oradea, Economic Science Series 21: 477-82.

Martinez Peria, Maria Soledad, and Sergio L. Schmukler. 2001. Do depositors punish banks for bad behavior? Market discipline, deposit insurance, and banking crises. The Journal of Finance 56: 1029-51. [CrossRef]

Menicucci, Elisa, and Guido Paolucci. 2016. The Determinants of Bank Profitability: Empirical Evidence from European Banking Sector. Journal of Financial Reporting and Accounting 14: 86-115. [CrossRef]

Merz, Julia, and Michael Overesch. 2016. Profit Shifting and Tax Response of Multinational Banks. Journal of Banking and Finance 68: 57-68. [CrossRef]

Money.hu. 2021. Bankok és Pénzügyi Intézmények. Available online: https:/ /www.money.hu/bankok (accessed on 23 May 2021).

MTI-Hungary. 2020. Coronavirus. Available online: https:/ / hungarytoday.hu/coronavirus-hungary-banks-tax-banking (accessed on 9 April 2020).

Neves, Maria Elisabete Duarte, Maria Do Castelo Gouveia, and Catarina Alexandra Neves Proença. 2020. European bank's performance and efficiency. Journal of Risk and Financial Management 13: 67. [CrossRef]

Olson, Dennis, and Taisier A. Zoubi. 2011. Efficiency and bank profitability in MENA countries. Emerging Markets Review 12: 94-110. [CrossRef]

Oral, Muhittin, and Reha Yolalan. 1990. An empirical study on measuring operating efficiency and profitability of bank branches. European Journal of Operational Research 46: 282-94. [CrossRef]

Osvat, Krisztina, and Szabolcs Osvat. 2010. Bank Tax in Hungary Quick Analysis on a Debated Pioneering Step. Working Paper Series; Acton: ANU Centre for European Studies.

Partnoy, Frank, and David A. Skeel. 2006. The promise and perils of credit derivatives. University of Pennsylvania Law School 75: 1019-56.

Puławska, Karolina. 2020. Effects of the bank levy introduction on the interbank market. International Journal of Finance $\mathcal{E}$ Economics. [CrossRef]

Reinhart, Carmen M., and Kenneth S. Rogoff. 2013. Banking crises: An equal opportunity menace. Journal of Banking E Finance 37: 4557-573. [CrossRef]

Sahyouni, Ahmad, and Man Wang. 2018. The determinants of Bank Profitability: Does Liquidity Creation matter? Journal of Economics and Financial Analysis 2: 61-85. [CrossRef]

Salas, Vicente, and Jesus Saurina. 2002. Credit risk in two institutional regimes: Spanish commercial and savings banks. Journal of Financial Services Research 22: 203-24. [CrossRef]

Shleifer, Andrei, and Robert W. Vishny. 2010. Asset fire sales and credit easing. American Economic Review 100: 46-50. [CrossRef]

Single Resolution Mechanism Regulation. 2014. Regulation (EU) No 806/2014 of the European Parliament and of the Council of 15 July 2014 establishing uniform rules and a uniform procedure for the resolution of credit institutions and certain investment firms in the framework of a Single Resolution Mechanism and a Single Resolution Fund and amending Regulation (EU) No 1093/2010. Official Journal of the European Union. Available online: https: / eur-lex.europa.eu/legal-content/EN/TXT/?uri=celex\%3A32014R0806/ (accessed on 23 May 2021).

Song, Fenghua, and Anjan V. Thakor. 2007. Relationship banking, fragility, and the asset-liability matching problem. The Review of Financial Studies 20: 2129-177. [CrossRef]

Statista. 2019. Foreign Ownership of the Banking System as a Share of Total Banking Assets in Germany from 2012 to 2019. Available online: https:/ / www.statista.com/statistics/810178/bank-assets-under-foreign-ownership-germany-europe-eu/ (accessed on 23 May 2021).

Tennant, David, and Richard Sutherland. 2014. What types of banks profit most from fees charged? A cross-country examination of bank-specific and country-level determinants. Journal of Banking E Finance 49: 178-90.

Tran, Vuong Thao, Chien Ting Lin, and Hoa Nguyen. 2016. Liquidity creation, regulatory capital, and bank profitability. International Review of Financial Analysis 48: 98-109. [CrossRef] 
Umlauf, Steven R. 1993. Transaction taxes and the behavior of the Swedish stock market. Journal of Financial Economics 33: 227-40. [CrossRef]

Warfield, Terry D., and Thomas J. Linsmeier. 1992. Tax planning, earnings management, and the differential information content of bank earnings components. Accounting Review 67: 546-62.

Yang, Zhenni, Christopher Gan, and Zhaohua Li. 2019. Role of bank regulation on bank performance: Evidence from Asia-Pacific commercial banks. Journal of Risk and Financial Management 12: 131. [CrossRef] 